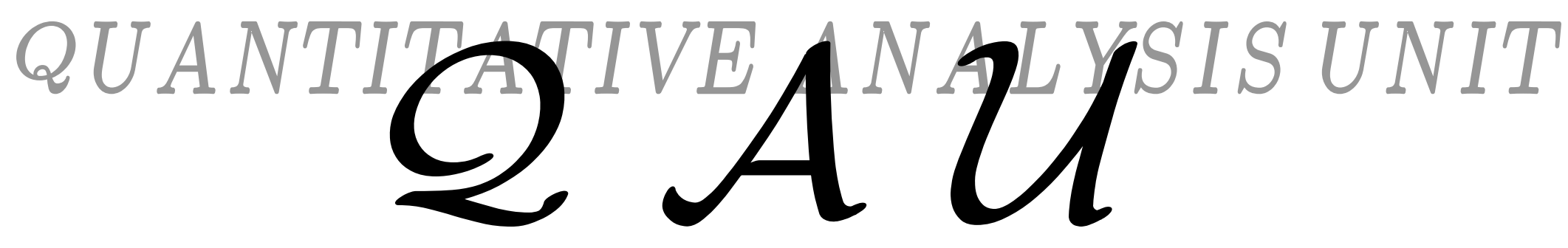

\title{
Your House OR Your CREDIT CARD, WHICH WOULD YOU CHOOSE? \\ PERsonal Delinquency TRADEOFFs AND PRECAUTIONARY LIQUIDITY MOTIVES
}

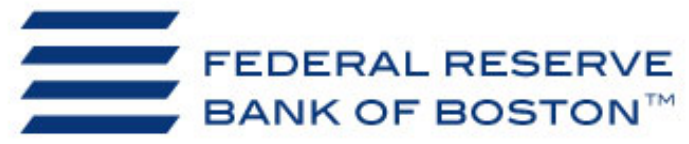

Working Paper No. QAU09-5
Ethan Cohen-Cole

University of Maryland - College Park

Jonathan Morse

Federal Reserve Bank of Boston
This paper can be downloaded without charge from:

The Quantitative Analysis Unit of the Federal Reserve Bank of Boston

http://www.bos.frb.org/bankinfo/qau/index.htm

The Social Science Research Network Electronic Paper Collection: http://www.ssrn.com/link/FRB-Boston-QuantAnalysis-Unit.htm 


\title{
Your House or Your Credit Card, Which Would You Choose?
} Personal Delinquency Tradeoffs and Precautionary Liquidity Motives

\author{
Ethan Cohen-Cole* \\ University of Maryland - College Park
}

\author{
Jonathan Morse \\ Federal Reserve Bank of Boston
}

January 28, 2010

\begin{abstract}
This paper presents evidence that precautionary liquidity concerns lead many individuals to pay credit card bills even at the cost of mortgage delinquencies and foreclosures. While the popular press and some recent literature have suggested that this choice may emerge from steep declines in housing prices, we find evidence that individual-level liquidity concerns are more important in this decision. That is, choosing credit cards over housing suggests a precautionary liquidity preference.

By linking the mortgage delinquency decisions to individual-level credit conditions, we are able to assess the compound impact of reductions in housing prices and retrenchment in the credit markets. Indeed, we find the availability of cash-equivalent credit to be a key component of the delinquency decision. We find that a one standard deviation reduction in available credit elicits a change in the predicted probability of mortgage delinquency that is similar in both direction and nearly double in magnitude to a one standard deviation reduction in housing price changes (the values are $-25 \%$ and $13 \%$ respectively). Our findings are consistent with consumer finance literature that finds individuals have a preference for preserving liquidity - even at significant cost.
\end{abstract}

*Ethan Cohen-Cole: Robert H Smith School of Business. 4420 Van Munching Hall, University of Maryland, College Park, MD 20742. email: ecohencole@rhsmith.umd.edu. (301) 541-7227. Jonathan Morse: 600 Atlantic Avenue, Boston MA. email: jonathan.morse@bos.frb.org. The authors are grateful to Yiorgos Allayannis, George Aragon, Ezra Becker, Zahi Ben-David, Jonathan Berk, David Dicks, Janice Eberly, Alex Edmans, Mark Flannery, Paolo Fulghieri, Diego Garcia, Adair Morse, Judit Montoriol-Garriga, David Musto, Adriano Rampini, Anil Shivdasani, Anjan Thakor, Peter Tufano, Haluk Unal, and seminar participants at the American Economic Association meetings, the FDIC-JFSR 9th annual research conference, George Washington University, Fannie Mae and the Jackson Hole Finance Group for helpful comments. Cohen-Cole thanks the FDIC Center for Financial Policy and the Robert H Smith School of Business for financial support. The views expressed in this paper are those of the authors and do not necessarily reflect those of the Federal Reserve Bank of Boston or the Federal Reserve System. 
For years, the conventional wisdom in the consumer finance industry has been that a consumer will pay their mortgage bill long after they have gone delinquent on other financial obligations. This paper finds strong evidence that many individuals in fact make the opposite choice, paying credit card bills even at the cost of mortgage delinquencies and foreclosures. Indeed the recent crisis has highlighted that many may do so because of housing price declines. We find an alternate motivation for this choice: the availability of cash equivalent credit. Empirically, a one standard deviation drop in available credit on credit cards lead to an increase in mortgage delinquency of $25 \%$. Indeed, the number of people choosing to become delinquent on mortgages while paying on their credit cards increased by a full 127\% between June of 2006 and December of 2007. ${ }^{1}$ Our inference from these patterns is the presence of a high precautionary demand for liquidity; individuals wish to ensure future access to lines of credit to cover regular costs of living. ${ }^{2}$

The fact that housing loans come with collateral not only makes these decisions particularly surprising, but also had led to the general perception that mortgages were a much safer lending option than credit cards. In the past couple of years; however, the decline in housing prices has called into question consumer preference for paying mortgages before other obligations. ${ }^{3}$ As almost a quarter of US homeowners are now underwater on their mortgages by the end of November, 2009, this concern remains in the political spotlight. $^{4}$

Our analysis below shows that amongst the varied potential explanations for this phenomenon, liquidity concerns play a central and dominant role. Indeed, they are of larger magnitude than housing price changes, which have been highlighted both in the popular press and the finance literature as a primary cause of mortgage delinquency. This result suggests that recent attempts to modify mortgages to assist borrowers may be unsuccessful; not because of strategic default decisions of borrowers but because lack of access to alternate forms of liquidity means that continued economic distress or a subsequent minor shock can push a borrower to protect his credit cards and drop even the modified mortgage. In addition to individual level shocks, a reduction in the supply of credit can have similar impacts. This past year, the Credit Card

\footnotetext{
${ }^{1}$ While to our knowledge, this paper is to first to tackle the question of delinquency priority, a recent paper (Lusardi and Tufano, 2009) makes the argument that a study of consumer credit must include the joint-probabilities across types of credit and delinquency behavior. They also provide survey evidence from 1000 individuals for a wide panel of behaviors and product usage.

${ }^{2}$ Indeed, Transunion has found evidence that "consumers...have become more conscientious in protecting those credit instruments still available to them and are making every effort to pay their credit card bills on time." http://newsroom.transunion.com/index.php?s=43\&item=516. Downloaded April 15, 2009.

${ }^{3}$ Guiso, Sapienza and Zingales, (2009) find that $26 \%$ of all individuals who default on their mortgage are capable of paying their mortgage. The topic of strategic default has become ever more salient in the current environment. This literature, in general, considers if housing price declines are a sufficient condition for agents to engage in strategic default behavior. A WSJ editor also published his own potential plan to default strategically as recently as December 2008 (see http://online.wsj.com/article/SB10001424052748704240504574585873167451840.html)

${ }^{4} 23 \%$ of homeowners according to data from First American CoreLogic. See http://online.wsj.com/article/SB125903489722661849.html
} 
Accountability, Responsibility, and Disclosure (CARD) Act imposed additional requirements on lenders that will limit fee income and likely reduce lending to low quality borrowers. This could exacerbate existing difficulties with mortgage modification programs.

We believe the role of liquidity is important for a few reasons. One, the consumer finance literature has found liquidity concerns to be particularly salient (see, for example, Telyukova, 2009). Our paper supports these findings. Individuals under increasing credit constraints find liquidity to be of increased relevance. This finding mirrors the corporate finance literature's conclusions on the use of lines of credit as committed liquidity insurance. ${ }^{5}$ Two, we will show below that when liquidity concerns lead to delinquency increases, they can have systemic implications. As liquidity concerns increase and foreclosures follow, neighboring houses can experience price declines, which trigger additional delinquencies.

Our empirical strategy follows four steps. To start, our goal is to isolate a group of individuals that are in the position to choose between their house and their credit cards. That is, we wish to evaluate individuals that have faced a shock large enough to force a delinquency, but not one large enough to force a financial catastrophe. We do so as follows. We begin with individuals in June of 2006 who had both a credit card and a mortgage, but no current delinquencies. In December 2007, we assess the individuals again and keep only those that experienced a delinquency on one type of loan, either their mortgage or their credit cards. We exclude those that become delinquent on both or none. Thus, we isolate individuals who have an effective option on the type of debt they wish to keep and on the type they wish to enter delinquency. We highlight this group as these individuals have some ability to direct their financial resources, providing us the ability to assess the tradeoffs they make in isolation of other concerns.

Our second step allows us to marry this information with specifics on individual liquidity position. Our measure of liquidity is the amount of available credit at the beginning of our sample period. Available credit is measured is the total credit line net of any balances already incurred. Because we begin with individuals that had no delinquencies in June of 2006, we can interpret this amount as the liquidity already available at the time of the shock. Similarly to corporate insurance, available credit can be interpreted as liquidity insurance. Our data permit precise information on all credit lines, mortgages, and other types of debt held by the individual in June of 2006. We show in Figure 1 the average available credit for individuals during the months leading up to a delinquency. The pattern in this figure is consistent with individuals preparing

\footnotetext{
${ }^{5}$ See, among others Boot, Thakor, and Udell, 1987, Berkovitch and Greenbaum, 1991, Campello, et al, 2009, Holmstrom and Tirole, 1998, and Thakor, 1995. This literature broadly finds the finds use lines of credit as liquidity insurance. While some recent work (Huang 2009) finds that the insurance is imperfect, it nonetheless fulfills a role that is conceptually similar to the consumer need.
} 
for the shock by increasing liquidity access ex-ante. ${ }^{6}$

Our third step evaluates the rationale for the decision to keep one type of debt versus the other. With our measure of liquidity, we can now estimate a binary choice model of the decision to choose delinquency on credit cards or mortgages. Such a choice has many potential influences; indeed, because of the detail available in the dataset, we will be able to control for a wide range of them. In addition to the credit available at the time of the delinquency choice, the choice itself has asymmetric influences on the ability to obtain new credit in the future. We will show that missing payments on a credit card costs marginally more in terms of access to credit cards than missing payment on a mortgage. As well, changes in housing prices can influence this choice. If housing princes fall, the incentive to repay mortgages fall, even if individuals are financially capable of making payments. This phenomenon is discussed in Guiso, Sapienza and Zingales (2009). We evaluate each of these concerns as well as a range of other potential influences, including various credit constraints, the availability of other types of cash equivalents such as home equity lines of credit, the availability of payday loans, and the relative scale of mortgages.

We find in each case that the role of liquidity is the predominant factor in the delinquency decision. Indeed, individuals in areas with large housing price declines respond to that incentive by choosing to protect credit cards; remarkably, the liquidity effect is nearly identical in areas that had not yet had price declines in 2007 (see Figure 2). This is consistent with the story that individuals refuse to pay as their mortgages rise above 100 percent loan to value ratio. However, it shows that the liquidity effect is salient across contexts.

Finally, we briefly illustrate the potential for spillovers to the remainder of the economy. This is important in particular in understanding the consequences of government intervention programs. The mechanism for this is straightforward and comes from existing literature on the impact of foreclosures on surrounding home values. ${ }^{7}$ To quantify the magnitude of the choices to stop paying on mortgages rather than credit cards, we regress community level delinquency rates on the individual-level mortgage delinquency. To handle endogeneity, we instrument the mortgage delinquency decision with the liquidity measure we show to be a predictor. This sheds light on the pass-through from individual tradeoffs to systemic difficulties. Notably, we find that this impact is both economically relevant and passes through only to mortgage delinquency, not to credit cards. Decreases in liquidity actually increase community level credit card payment probabilities. This implies that changes in regulation on credit cards may have perverse impacts on credit and mortgage

\footnotetext{
${ }^{6}$ It is worth noting that this does not reflect increased credit causing delinquency. Indeed, utilization rates decrease linearly during the time leading up to a delinquency. Emphasizing the role of credit limits as liquidity insurancec for unexpected shocks, the pattern in Figure 1 is reversed for individuals prior to bankruptcy. Because a bankruptcy filing comes with the ability to expunge debt, instead of building a precautionary buffer, these borrowers on average use up remaining credit. This suggests that the predelinquency borrowers in our dataset are not strategically defaulting, at least with the intention of bankruptcy.

${ }^{7}$ A survey of this literature is available in Lee (2008) and in a Center for Responsible Lending report (2008).
} 
delinquency rates.

Indeed, because we are able to identify individuals who have undergone a mild economic shock as well as isolate the delinquency decision, we can answer one of the questions at the core of the debate about the initiation and spread of the current financial crisis: is the delinquency decision motivated by housing prices concerns? This question is of notable relevance in the current environment, because we have seen both a dramatic changes in housing prices as well as a significant reduction in the availability of consumer credit. ${ }^{8}$

The remainder of the paper is structured as follows. After a review of stylized facts that characterize the tradeoffs that we are discussing, Section II provides a summary of the relevant literature and Section III the relevant market. Section IV details our econometric methodology. We continue in Section V to describe our data. Section VI provides results and sensitivity tests. In Section VII we discuss economic spillovers and Section VIII concludes.

\section{I.1 Stylized Facts}

We provide some additional information here to motivate the study. Using panel data on 2.2 million individuals from 2006 and 2007, described in more detail below, we can assess the probability that individuals choose one type of delinquency over another. To begin, we isolate the approximately 350,000 individuals that have a mortgage and some type of revolving credit in both June 2006 and December 2007. Then, we subdivide the sample into individuals that were delinquent on one of these credit products in each time period. A summary of the facts presented here is available in Appendix T1.

Fact 1: A large fraction of individuals choose delinquency on mortgages or credit cards, but not both.

Fact 2: A large fraction of these individuals choose delinquency on mortgages while continuing payment on credit cards.

Of the sample of individuals that have a mortgage in 2006 and 2007, 9,290 have had some type of credit card delinquencies in the sample time period. However, 8,339 have had some type of mortgage delinquency. Given that there is imperfect overlap in these groups, a substantial fraction of individuals are choosing to become delinquent on housing but not on their credit cards. Indeed, a full 6,187 of the 8,339 (or about $74 \%$ ) had this profile. The converse is also true. Of the 9,290 that choose credit card delinquency, 7,138 (about $77 \%$ ) did so without any late mortgage payments (see Table I).

These statistics are remarkable for two reasons. One, a large fraction of consumers are making choices about which debt to cover when faced with economic hardship. Our current models of distress (principally

\footnotetext{
${ }^{8} \mathrm{An}$ anecdotal pattern has emerged indicating that protecting consumer credit lines may be an increasingly important factor in delinquency decisions. An example from December 2008, USA Today profiled a woman who missed a single payment and lost well over half her credit line. Kathy Chu, "Changing credit card terms squeeze consumers," USA Today, December 15, 2008.
} 
bankruptcy studies) regard overall economic condition alone, or speak to strategic run-up of unsecured debt prior to bankruptcy. The small scale of the average delinquency $(<\$ 1000)$ and the number of individuals in the sample suggest that the observations are not pre-bankruptcy behavior. Indeed, an insignificant fraction of individuals that are delinquent in 2006 become bankrupt by 2007.

Fact 3: As delinquency rates have risen overall, the proportion choosing mortgage delinquency over credit cards has risen.

It is well known that economic conditions deteriorated between June 2006 and December 2007 (and more since that point). During that time, delinquency and default rates increased for most groups of individuals. For the purposes here, the notable change was the difference between credit card and mortgage delinquencies. Individuals that were mortgage delinquent but not credit card delinquent increased 127\% during the 18 month period. Individuals that were credit card delinquent but not mortgage rose $18 \%$.

\section{Literature}

The nascent literature on consumer financial decision making has not yet, to the authors' knowledge, tackled the question of delinquency priority, or its effects on the economy. As noted above, Lusardi and Tufano (2009) provide detailed information on the conditional probabilities of financial product usage and behavior across 1000 individuals and more than a dozen products. Tufano (2009) also provides an overview of this new literature.

In addition to the work cited above, the closest antecedents are the literatures on consumer bankruptcy decisions and non-traditional lending.

Consumer bankruptcy emerges out of the same patterns of financial distress that, in generally smaller amounts, lead to the delinquency tradeoffs discussed in this project. Indeed, there has been a large rise in bankruptcies over the last few decades. The bankruptcy literature, to date, partitions the reasons for bankruptcy into two types. ${ }^{9}$ The first considers increases in idiosyncratic uncertainty due to changing labor earnings volatility or decreases in medical insurance coverage (Barron, Elliehausen, and Staten, 2000, and Warren and Warren Tyagi, 2003). This category also captures the demographic scenario that argues that the passing of the baby-boomers through the prime bankruptcy ages and changing family structure have increased the number of risky households (Sullivan, Warren, and Westbrook. 2000). Another study (Cohen-Cole, 2009) finds that risk has been increasing across the spectrum of households and the bankruptcy decision is indeed a function of this exposure.

\footnotetext{
${ }^{9}$ See White (2007) for an excellent review.
} 
The second category is the role of the changes in the credit market environment that have made bankruptcy more attractive or expanded credit to a broader set of households, including higher-risk ones (see Dick and Lehnert, 2009, for a recent example). Similarly, Cohen-Cole, Duygan-Bump and MontoriolGarriga (2009) find that access to credit after bankruptcy has dropped for low credit quality individuals more than high credit quality ones. Both of these suggest that changes in the regulatory environment for credit cards could have asymmetric impacts on credit access.

This second set of explanations includes the story that credit market innovations (such as the development and spread of credit scoring) facilitated the increase in credit granted to households by reducing the transaction costs of lending (Athreya 2004). But it also includes the possibility that the personal costs incurred by delinquent individuals have fallen substantially, either as a result of improved bankruptcy filing procedures, the learning by households from each other as to how to navigate the bankruptcy process, or a decrease in social stigma associated with delinquency. ${ }^{10}$

Non-traditional lending research is potentially useful as well for an understanding of delinquency tradeoffs as users of payday lending and similar fringe products are often in situations of financial distress or unable to access traditional markets. This literature does not provide a direct analysis of tradeoffs between types of delinquency, but does offer some perspective on why individuals may choose to use payday loans. A summary of this literature is available in Skiba and Tobacman (2008). The same authors find in a prior paper that the use of payday loans is explained by a combination of consumer shocks and very high discount rates (Skiba and Tobacman, 2005). Agarwal, Skiba and Tobacman (2009) find evidence that consumers will even open payday credit lines before using all available consumer credit. The implication, for delinquency tradeoffs, is that strategic consumers that find themselves in a financial stress situation, may resort to protecting their credit cards rather than their houses.

On a related topic, Cole, Thompson and Tufano (2008) provide some detailed evidence of spending patterns of credit constrained households. While they do not directly address delinquency, they find strong patterns of spending choices that vary according to the severity of credit constraints.

This paper seeks to contribute to the outstanding literature by providing both an empirical analysis of financial decision making in periods of financial distress prior to or in place of bankruptcy and that decisions impact on the regional trends in housing price movements. This involves individual-level delinquency tradeoffs. Importantly, this paper will also assess spillovers from current housing market stress into financial decisions and vice-versa. If many individuals choose to protect personal liquidity, at the expense of their home payment, there can be changes in aggregate housing values.

\footnotetext{
${ }^{10}$ See Cohen-Cole and Duygan-Bump (2010) for more on social effects and bankruptcy.
} 


\section{The Market}

We digress briefly to discuss the market that we treat in this study. Our analysis is focusing on understanding the consumer tradeoff between a delinquency on credit cards and on a mortgage. In this section we will discuss the definition of delinquency and default, as well as some patterns in the credit industry. While credit card and mortgage products are likely understood by most readers, a short description is useful. Credit cards are consumer orientated lines of credit. Individuals agree to a schedule of fees and prices and lenders then provide access to a pre-determined line of credit. Both the fee and price schedules as well as the line itself are subject to changes by the lender. For example, lenders may reduce, discontinue, or accelerate repayment on lines for borrowers that fail to make timely monthly payments. Issuers similarly may increase the size of the lines often based on a prior history of payment. Though most credit cards lines are unsecured, banks also provide payment services on secured cards. For these cards, each dollar of available credit line has to be secured with advance cash balances.

The availability and size of lines of credit available to an individual is a function principally of an individuals' credit quality. Credit quality is largely determined in this industry through the use of credit scores. These scores are typically inverse ordinal rankings of risk. That is, an individual with a credit score of 200 is viewed to have higher risk of default than an individual of score 201. Furthermore, most credit scoring systems currently in use are based on a logarithmic scale, meaning the difference in risk between 200 and 201 will not be equal to the change from 201 to 202. As well, because the ranking is an ordinal one, the change between the scores may not be proportional to the log difference either. To determine a score, an issuer or other data provider will regress failure to pay on a wide variety of borrower credit characteristics. These can include prior late payments, amount of available credit, utilization rates, number of new credit lines, and more. Once a score is obtained, issuers then use the score in combination with a range of other variables that may be unique to the issuer, to determine the credit line.

Credit cards have become increasingly popular not only as means of payment, but also as a way to manage cash flow and economic shocks.

One a line has been opened, issuers routinely assess borrowers' probability of payment and adjust lines accordingly. During early parts of this decade and much of the 1990s issuer would regularly provide additional, unsolicited, credit to borrowers. Repayment rates were historically high, funding easily available and interest spreads large. This increased availability allowed many individuals to rely on their cards as a source

of conditional liquidity. As the crisis hit late in the decade, issuers began to reduce lines more frequently in part due to funding shortages, in part due to the declining credit quality of borrowers, and potentially now 
due to new regulations. For the purposes of this paper, the question is how this contracting liquidity provision impacted borrowers decision making under stress. Once our individuals have to face a delinquency, do they keep paying their credit cards in order to avoid the penalties that result from non-payment?

Mortgages are also well known. The main feature of mortgages for this paper is that they are collateralized by a fixed asset, a house. Unlike credit cards, primary mortgages are for a fixed amount. Changes in this amount require refinancing at some time and financial cost. Because mortgages are for a fixed amount, neither lenders nor borrowers can adjust easily to meet changing economic or credit quality conditions. During the expansionary credit period of the late 1990s and early 2000s, home equity lines of credit (HELOCs) became increasingly popular. These lines are similar in structure to credit cards, with the exception that they are secured by the house. Default on either a mortgage or a home equity line will trigger a default on the other.

Below, we will use changes in the score that result from delinquency to understand whether housing or credit card delinquencies are more likely to impact both current credit and the ability to obtain new credit.

In most markets and for most products, a lender can decide that a loan is in default after a single missed payment. In practice, most credit card and mortgage lenders will wait to enforce a default provision until payments are 90 days or more late. Lesser delinquencies of 30 or 60 days late are typically reported to credit bureaus, and thus show up in our data, but are not considered defaults. Lenders may wait for a variety of reasons including a) collecting debt can be expensive b) moderately late borrowers may recover and c) late borrowers can be lucrative as a result of penalty fees.

We choose to focus on 60 day delinquencies for a variety of reasons. Unlike 30-day delinquents, most individuals that become 60 days delinquent on a debt will eventually become 90 days delinquent. As a result, using the 60 day delinquencies provides insight on which credit product an individual desires to keep. While they may eventually recover, the decision at the 60 day point is a crucial one. Second, once a homeowner defaults on a mortgage, there are a range of legal and institutional differences in how these are treated. For example, in some states, first-lien primary residence home loans are recourse loans, allowing a lender to claim property other than the primary residence in the event of default. By focusing on the consumer decision, prior to the onset of legal differences in treatment, we can highlight the delinquency choice carefully. 


\section{Econometric Methodology}

Our goal, as discussed, is to highlight the decision making amongst individuals facing moderate financial distress. This is a particularly salient question because these individuals face a peculiar tradeoff - one that has potential economic spillovers. Neither those facing extreme distress nor those under little distress must choose between paying a household mortgage or paying credit card debt. Specifically, we include individuals that have at least one mortgage and at least one revolving credit line in June of 2006. At that point, they do not have delinquencies on either product. ${ }^{11}$ As of 2007 , we include only individuals that have incurred a delinquency on one or more mortgages or one or more cards. However, we do not include individuals that have delinquencies in cards and mortgages. This structure allows us to isolate the correlates of the individuals that faced this particular type of shock. In principle the type and magnitude of the shocks will be heterogeneous, but the outcome of the shocks homogeneous. That is, a wealthy individual may need to be hit with a series of large shocks or a poor individual with one minor shock to reach this economic condition. However, this is a useful tool in that it allows us to evaluate a highly heterogeneous population in terms of wealth, income, race, education, etc. but nonetheless evaluate a common set of decisions.

Once we've defined our population and shocks, we can move to evaluating the decision itself. Of course, there are a range of reasons why an individual would choose one type of delinquency over another? We consider a wide range here, beginning with housing prices and liquidity concerns. As collateral values fall, making home payments may no longer be optimal. As well, access to cash after a financial shock may be important to some individuals. Among the sources of cash available to individuals are the open lines of personal credit cards. Thus, the amount of credit one had prior to a shock reflects availability of resources to manage that shock. Ability to access new credit may also be important, and we return to this topic below.

We define a variable, $C C \prec M T$, which uses the preference relation, $\prec$, to indicate that an individual prefers her house to her credit cards. Thus, a revolving credit delinquency is coded as a 1 indicating that individuals chose the house. We can then estimate

$$
\operatorname{pr}(C C \prec M T)_{i}=\Phi\left(\alpha+\beta_{1} Y_{j}+\beta_{2} X_{i}+\beta_{3} \text { price }_{j}+\beta_{4} \text { liquidity }_{i}+\varepsilon_{i}\right)
$$

where price $_{j}$ is a local measure of housing prices and liquidity $_{i}$ is an individual level measure of credit available to the individual at the beginning of our sample, before the delinquency in question. Our baseline measure is the amount of unused revolving credit available to the individual in June 2006. This is calculated

\footnotetext{
${ }^{11}$ These individuals may have other debt, including car loans, payday loans, etc. In our sensitivity analysis below, we explore the role of other types of debt.
} 
as the total credit line from all credit cards net of current balances. This ex-ante measure is useful because it provides a measure of the economic condition of the individual prior to the onset of financial distress. Recall that the sample is defined as individuals without delinquencies in June of $2006 .{ }^{12}$ A detailed list of individual and community level controls can be found in Table II.

We believe that individuals choose the type of delinquency based on two factors: one, the economic value of the underlying asset, the house and two, the consumption value of consumer credit in relieving the individual budget constraint.

\section{Data}

This paper draws primarily on a very large proprietary data set provided under contract by Transunion, one of the three large US credit agencies. The data are drawn from stratified random samples of individuals and include information from personal credit reports. In particular, the file includes individual date of birth, a variety of account and credit quality information such as the number of open accounts, defaulted accounts, current and past delinquencies, amount of past due balances, credit lines, credit balances, etc. The information spans all credit lines, from mortgages, bank cards, installment loans to department store accounts. Transunion also provides a summary measure of default risk (a generic credit score). As is customary, account files have been purged of names, social security numbers, and addresses to ensure individual confidentiality. However, they do provide geo-coding information that allows us to match these personal credit history files with information from the US Census; again, in a manner in which confidentiality is maintained.

One of the benefits of the credit database used here is that it includes a measure of credit risk. For each individual, Transunion includes a proprietary generic credit score. As in Gross and Souleles (2002) and Cohen-Cole, Duygan-Bump, and Montoriol-Garriga (2009), this paper uses the score as a control for changes in the risk composition of borrowers, together with account information on credit lines, balances, and utilization rates. The data were drawn from credit reports from the middle of 2006 and the end of 2007. It is comprised of a very large short panel of about 2.2 million individuals. The very large size of the dataset is useful in particular in helping to understand the heterogeneity present in the data while maintaining explanatory power.

For this paper, we draw on detailed information on borrower delinquency and utilization patterns. Transunion includes information on sixty day delinquency patterns for each type of credit. We exploit this vari-

\footnotetext{
${ }^{12}$ For our measure to be appropriate, we need that individuals, prior to delinquency, have then-optimal desired levels of available credit. Given that we have excluded individuals who went bankrupt before our first sample date from the sample as well as those who are unwilling or unable to pay all of their debt, we see little reason to believe why an individual would increase available credit lines with the plan to avoid payment on one of them.
} 
able's ability to distinguish between individuals who faced a shock and those who casually miss payments to identify distressed individuals. Thus we categorize an individual that has a balance that is at least sixty-days past due to be delinquent in the respective credit type. In terms of utilization, we compute an individual's unutilized revolving credit from their revolving credit limit and their current revolving credit balance. Given the availability of geo-coding information for the individuals, one can compute local delinquency rates.

The Transunion data also have a number of advantages for our study. First, these data allow us to look at various features of borrowing and delinquency behavior without concern for measurement error. Second, there are many individuals who meet our narrow set of conditions (not delinquent in 2006 and delinquent on only one type in 2007). Our key disadvantage is that we have no direct information on household income or employment status. This led to our choice of a subsample which isolates the individuals who faced some type of financial shocks.

\section{Census Data and Other Information}

Together with the credit information, the paper uses an individual's geo-coded census block address from the Transunion data and links a wide variety of information on location characteristics. In particular, because there is no individual-level data on variables such as income and education, the paper relies on the following variables to control for local economic and demographic conditions. For demographic controls (education, race, and marital status), the paper uses data from the US 2000 Census national summary files and merges information at the neighborhood level (defined as a 1 mile radius). The paper uses data on median household incomes and poverty rates from the US 2000 Census and the 2005 and 2006 American Community Surveys at the county level. One can also match information from the Current Population Survey and Local Area Unemployment Statistics of the BLS on health insurance coverage (at the state level) and unemployment rates (at the county level), respectively, for the corresponding years. By using this degree of granularity, one can control a degree of the heterogeneity in economic shocks faced in the US economy.

Finally, to capture the house price dynamics we take quarterly price data from the Office of Federal Housing Enterprise Oversight at the state level.

When all this information has been merged a certain number of individuals get dropped due to missing data, for example on credit scores. Once these and other similar missing observations are removed, the paper has a short panel of about 350,000 individuals. Appendix T1 presents some summary statistics. 


\section{Delinquency Tradeoffs}

\section{VI.1 The Revolving vs Mortgage decision}

As explained above, our core methodological approach is to isolate the population of interest and illustrate the primary factors impacting their decision. We begin with a description of our primary results. Table II shows the results of a probit regression of the binary variable $(C C \prec M T)$ on a range of individual financial controls, local demographic information and local economic indicators. As well, the specification includes our variables of interest: housing price changes and availability of credit. We measure housing prices changes over two time periods: 2000-2007 and 2006-2007. The two allow us to capture differential response to long run price trends and short term shocks. Recall that our data sample extends from June 2006 to December 2007, so the price changes are those that occurred relatively early in the crisis - in fact, our sample contains only eleven markets with year-on-year price declines.

Our dependent variable equals 1 if an individual was not delinquent in June 2006 and became delinquent on at least one of her credit cards in December 2007, but not on her mortgage and equals 0 if the same individual was delinquent on her mortgage in 2007 and not any of her credit cards. Columns 1-3 show that, in general, housing price trends are positively correlated with the dependent variable. The intuition is straightforward, during a time period of rising housing prices, when faced with a delinquency choice; individuals choose to defer payment on their credit cards rather than the increasing value asset.

In Columns 4 and 5, we show that our measure of liquidity, currently available revolving credit, is positively signed as well. As liquidity increases, individuals become delinquent on their credit cards in place of their mortgage. When faced with lower liquidity, individuals appear to choose mortgage delinquency in order to protect the available remaining credit on their credit cards. Since credit cards are largely a cash substitute, this serves as a potential buffer against economic shocks. Notice that the coefficients on the liquidity variable are nearly identical across specifications, suggesting little concern that it may be picked up housing price effects.

Table II reports all regressions with details on demographic and financial control variables. We find that most demographic indicators, after controlling for credit score, are not significant predictors of the mortgage versus credit card decision. Indeed, with a few exceptions, education levels, marital status, median block-level household income, prevalence of health insurance, and public assistance levels all show a lack of significant relationship to our dependent variable. We do find that those with higher credit scores will choose to protect their houses. As well, individuals in primarily Black and Hispanic neighborhoods will protect their credit cards. That said, areas with higher poverty rates have a strong preference for protecting 
their houses. Age has an expected relationship, with the young more likely to choose liquidity (see section below). We suppress these coefficients in subsequent tables.

\section{VI.2 Nonlinearities}

As our liquidity indicator appears strongly significant, one would expect that this effect would be stronger for individuals with low liquidity; lack of access to cash equivalent resources becomes a significant issue only the closer one is to a binding financial constraint. To account for this, we evaluate the role of nonlinearities by including an additional term in equation 1 :

$$
\operatorname{pr}(C C \prec M T)_{i}=\Phi\left(\alpha+\beta_{1} Y_{j}+\beta_{2} X_{i}+\beta_{3} \text { price }_{j}+\beta_{4} \text { liquidity }_{i}+\beta_{5} \text { price }{ }_{j}^{2}+\beta_{6} \text { liquidity }_{i}^{2}+\varepsilon_{i}\right)
$$

Once nonlinearities are included in Table III, a one standard deviation increase in available credit leads to a $25 \%$ increase in the probability that a distressed individual will choose revolving credit delinquency over mortgage delinquency. To compare to the effect of housing price changes, an increase in the long term housing prices by one standard deviation decreases the probability that a moderately distressed individual will choose revolving delinquency over mortgage delinquency by $4.6 \%$; for short term price movements, the change is an increase of $14.3 \%$. One may expect that if credit cards provide liquidity support, individuals that have the highest degree of credit constraints will have the greatest need for this additional liquidity. From an empirical standpoint, this implies that individuals with the lowest availability of credit will have the highest marginal propensity to default on their mortgages for the liquidity reasons suggested.

\section{VI.3 Is a dollar a dollar?}

Consumers have access to a wide range of revolving accounts including credit cards issued by banks, credit cards issues by retail establishments, personal lines of credit as well home equity lines of credit (HELOCs). These lines have a few principal differences. First, HELOCs are mortgages. The credit is secured by a lien against the borrower's house. In practice, lenders have difficultly recovering much from a defaulting HELOC as there is typically insufficient collateral post default to cover the full amount of the first lien. ${ }^{13}$ Lenders provide lower interest rates on HELOCs than on similar lines of credit via credit cards, and higher

\footnotetext{
${ }^{13}$ This can occur due to under-collateralization (LTV $<100 \%$ ), transactions costs associated with re-sale of properties, or degraded value of property due to poor management and upkeep by the foreclosed property holder. It can also occur after bankruptcy. In most states, a chapter 13 bankruptcy restructuring allows a borrower to 'strip' off second and third liens, making HELOCs effectively junior to unsecured credit card debt.
} 
rates than on first lien mortgages. Second, revolving bank loans and retail cards are particularly easy to use as cash substitutes. Paying for groceries is easier to do with these means then via a HELOC.

In our data, we are able to distinguish between each of these forms of credit. For each, we calculate a similar liquidity measure as we did above:

$$
\text { available_credit }=\text { total_creditline }- \text { balance }
$$

We then compare the role of each in the decision to choose delinquency on revolving balances or on mortgages. To clarify, a mortgage delinquency is a delinquency on any lien. Note that failure to pay on a credit card does not necessarily trigger actions on other revolving lines, ${ }^{14}$ while a default on a second lien HELOC will trigger a default provision by the first lien holder. We present results from this analysis in Table IV. An additional dollar on credit cards is 1000 times more important than an additional dollar on a HELOC is making the delinquency decision. Notably as well, the relative impact of an additional dollar of credit is much larger for retail cards than for other form of credit. In particular, a dollar less of credit on a retail card is 10 times more likely to contribute to the decision to default on a mortgage than an additional dollar in a HELOC.

\section{VI.4 Payday Lending}

We continue evaluating whether access to alternate forms of cash substitutes impact our results. In this section, we look at the presence of payday lending in the proximity of the borrower. In particular, Table $\mathrm{V}$ includes the prevalence and regulations on payday lending at the state level to determine if the ease of access to alternate financing impacts the preference for liquidity. Essentially, if an individual is willing to maintain open lines of credit based on a precautionary demand for liquidity, on the margin, the presence and ease of access of payday loans should ameliorate this demand. For some individuals, having access to a payday loan, even at high cost, will minimize the demand for lines of credit.

To evaluate this question, we subdivide states into three groups as rough proxies for the prevalence of payday loan establishments. The results reveal a story consistent with the precautionary demand for liquidity. The liquidity proxy remains important in all states (housing prices do not), but the effect is about a third smaller in states with a large payday lending presence. Indeed, these are the only states in which any of our payday regulations appear significant. In those states, higher annual percentage rate regulatory limits

\footnotetext{
${ }^{14}$ Some issues pursued a policy during this time period called universal default. When a lender noticed a default on another card, it would trigger default provisions on its own lines, typically increasing interest rates to a penalty rate or lowering available credit lines.
} 
lead to increased propensity to default on credit cards rather than mortgages. We find this to be supportive evidence that the increased ability to obtain financing, at even very high rates, provides a form of liquidity support.

\section{VI.5 Credit Constraints}

The dearth of liquidity and its impact on delinquency decisions may be particularly salient for those that would have a higher chance of being credit constrained. Constraints can appear in a variety of contexts, and in this section we evaluate a range of them to illustrate that liquidity concerns become uniformly more salient as constraints bind. We address life-cycle concerns and credit histories in Table VI.

Beginning with age, we hypothesize that life-cycle patterns have a significant impact on the ex-ante credit constraints and thus, the young should show an increased need for liquidity. Table VI reports the age dependent results of our baseline regression. Unsurprisingly, for individuals under thirty the liquidity effect of delinquency is stronger than at any other age. It is precisely these individuals that have lower disposable income, lower savings, and lower available credit than at any point later in life. The preservation of available revolving credit in order to meet short term obligations is thus intuitive and supported by the data. This effect carries over into short term housing price fluctuations as well where they are more apt to stop paying on mortgages than their elder counterparts. On average, younger individuals have less equity in their homes than the older population; a result of larger down-payments and greater repayment of the principal by elder individuals. Perhaps more surprising is that the relevant coefficients for the middle age group, a group not traditionally associated with binding credit constraints, are also highly significant and of large magnitude.

The magnitude for these individuals reflect the same liquidity preservation seen earlier, however the smaller coefficient on the short term price fluctuations reflect the increased housing services that are derived from home ownership for middle aged individuals. This too is in line with our priors, middle aged individuals, whose homes represent the aggregation of important life decisions, are more apt to protect their mortgages than their younger counterparts. Finally, among the oldest group in our sub-sample we see only a weak relationship between the delinquency decision and credit availability and no relationship between the delinquency decision and housing prices.

Similar to our results for age, one would expect that individuals with lower credit scores are less able to obtain additional credit in the event of a shock. To evaluate, the final three columns of Table VI shows a decomposition of our primary results by credit score. Belying the notion that only poor credit individuals would encounter these types of situations; the results are largely consistent across the credit spectrum. Each 
of the three categories show positive and significant coefficient on the recent housing price change, with the largest effect arising for those with the best credit scores. The coefficients on the available credit variable are also unsurprising. As credit quality falls, available credit becomes increasingly important; the coefficient for the low credit quality is more than three times as large as the coefficient for the high credit quality individuals. Those with poor credit have a large incentive to defend their source of credit, particularly when faced with a financial shock.

\section{VI.6 Housing Prices and Local Distress}

In this section, we further explore the role of housing prices in predicting the type of delinquency. To account for variation in housing prices, we include two forms of housing price trends, a recent and a longerterm one, potential state or region-specific level shocks such as declining industries or particularly large spillovers from housing to other sectors may lead to different delinquency decisions. Specifically, we highlighted the importance of three particular states that saw large drops in housing prices and the apparent magnified impact, in those states, on changes in the delinquency decision. In this regard we saw that the distressed housing markets of Arizona, California, and Florida exhibit a dramatic increase in mortgage-only delinquents in our sample. In Table VII we give further support to this finding. The first four columns show the results of various specifications only for the ten states that experienced the worst housing prices declines by December of 2007. Indeed, by the end of 2007, only 11 states had shown price decline, so our decomposition is reflective of the differences in behavior between markets that have experienced a significant fraction of houses with negative equity and those that remain healthy.

Two results are worth noting. One, each of these regressions exhibit the same general trend as the baseline model, increasing revolving credit delinquency in housing price changes and unutilized revolving credit. In both cases, liquidity plays an important role in the delinquency decision. Two, the magnitude of the liquidity coefficients largely reaffirms the story above. Indeed, in the distressed markets, as expected, shortterm pricing changes are strong predictors of housing default. Conversely, in the non-distressed market, short-term changes in prices have no impact on the delinquency decision. More importantly for our purposes, the liquidity variables is of slightly greater magnitude in the non-distressed markets.

Figure 2 shows an expansion of this analysis. We report individual coefficients for individuals in each of 10 groups of states. We divide the state groups again by price changes over the time period from 2006 to 2007. For each group, we estimate a separate regression identical to those above. With the exception of the group of states with large price increases, the liquidity impact is largely the same across specifications.

The asymmetry of coefficient changes between the housing price and liquidity variables across specifi- 
cations is strong evidence that our liquidity variable is not biased. Notice that the liquidity variable shows a significant and large effect across states with varying degrees of price changes and across circumstances. As we change these specifications, the housing price variables change in expected ways. Jointly these imply that our measures capture the relevant phenomena.

\section{VI.7 Scale and delinquency}

Our sample in 2007 shows mean revolving credit card balances of approximately $\$ 17,000$ and mean mortgage balances of $\$ 148,000$. The payments on these each month are approximately $\$ 440$ and $\$ 1,300$, respectively. For those that choose credit card delinquency, our samples show that the credit card balances and mortgages balances are higher than the population averages. For those with mortgage delinquency, we see that mortgage balances increase versus the average and credit cards decline. To account for these difference, we show our primary results along with a control variable for the difference in expected monthly payments.

Monthly payments on credit cards during the time period of our study were typically $3 \%$ of outstanding principal. We assume that interest rates are on average $15 \% .{ }^{15}$ For the mortgages, we obtain the monthly payment directly from Transunion. Both of these will bias our results towards finding that the mortgage is much more expensive. The results of this exercise are in Table VIII. We find that having a larger mortgage payment relative to credit card payment leads, as expected, to a decreased probability of defaulting on ones credit cards; individuals with relatively large mortgage payments that are hit with an economic shock are likely to let the mortgage go first.

Importantly for our study, the coefficient on the liquidity variable of interest changes only slightly. Liquidity concerns are paramount even after controlling for scale of payments.

\section{VI.8 New Credit Access}

Our primary measure of liquidity is the amount of credit available to a borrower at the beginning of our sample (June 2006). Recall that we defined our sample to include only individuals that had no delinquencies; as such, an unexpected financial shock would leave the individual access to the credit that he or she had at the beginning of the sample. This indeed is part and parcel of the motivation for using the pre-shock credit access as a measure of liquidity insurance.

\footnotetext{
${ }^{15}$ This assumption is probably slightly low. The federal reserve G19 series reports that average credit card interest rates in May 2006 and November 2007 were 13.16 and 12.75 percent respectively. These dates were the closest reported to the dates of our sample. The rates include credit for a full range of borrowers. Since our sample are those that have a deliquency, the rates are likely to be much higher after the delinquency is declared. (see http://www.federalreserve.gov/releases/g19/hist/cc_hist_tc.txt

Note as well that recent changes from credit card issuers has led to $5 \%$ monthly principal payments. However, during the time of this study, $3 \%$ was the norm.

We use a conservative measure in each case to ensure robustness.
} 
Of course, once the shock hits, borrowers may be able to expand their access to credit by soliciting additional credit; however, once they fail to pay on an obligation, the convenants of the borrowing agreements allow issuers to reduce borrowing limits. For the time period that we analyze, issuers had the ability to impose so called 'universal-default' provisions. This allowed them to adjust rates and available credit lines for credit lines other than the one that became delinquent.

We evaluate here the expected credit cost of failing to pay on credit cards and mortgages, respectively. In particular, we will illustrate that while the cost of delinquency in terms of access to credit is relatively large, there is little difference between the type of delinquencies. In fact, any difference implies a greater incentive to default on mortgages, supporting our primary results.

Because the credit score is a good proxy for an individual's ability to obtain credit in the future, we begin by estimating a credit score penalty for each type of delinquency. To do so, we estimate the counter-factual credit scores that individuals would have, had they not become delinquent in either account.

First, using the sample of individuals that did not have any delinquency in either 2006 or 2007, we estimate the following model for the credit score in 2007 using observables in 2006:

$$
\operatorname{pr}\left(C S \_2007_{i}=1\right)=\Phi\left(\beta_{1} C S \_2006_{i}+\beta_{2} X \_2006_{i}+u_{i}\right)
$$

where $i$ is defined for all individuals and where $X \_2006=\left\{\right.$ age $_{i}$, income $_{i}$, race $_{i}$, etc. $\}$, and $C S \_2007$ and $C S \_2006$ are the credit scores in 2007 and 2006 respectively.

Using model 3, we predict the credit score in 2007 for the sample of $i$ individuals that have either mortgage or revolving credit delinquencies. This is the counterfactual: estimated credit score that an individual would have in 2007 if they had not been delinquent, conditional on their observable characteristics in 2006.

$$
\widehat{C S} \_2007_{j}=\widehat{\beta}_{1} C S \_2006_{j}+\widehat{\beta}_{2} X \_2006_{j}
$$

where $\widehat{C S} \_2007_{j}$ is the predicted score in 2007 for individuals that have either type of delinquency in 2007.

Next, we estimate the credit score penalty, conditional on delinquency type, for individuals that were delinquent in 2007 by subtracting the estimated credit score in (2) from the actual observed credit score in 2007.

Penalty $C C_{j}=C S \_2007_{j}-\widehat{C S} \_2007_{j} \quad \mid \quad i$ was CC delinquent $\&$ not mortgage delinquent in 2007

and

Penalty $M T_{j}=C S \_2007_{j}-\widehat{C S} \_2007_{j} \quad \mid \quad i$ was mortgage delinquent $\&$ not CC delinquent in 2007 
Table IX shows the two penalties and should make clear that there is little distinction between the two types of credit. Indeed, the credit score penalty for being late on revolving credit is only 18 points larger than for a similar delinquency on the mortgage side.

We repeat this methodology to explore how the availability of credit changes after a delinquency. We use two measures: the total credit of all revolving lines and the unutilized portion of these lines (limit-balance). The advantage of the latter measure is that it captures the balance available to individuals after the negative shock. The tables show that the penalty on limits for missing payments on a mortgage is about double that for missing payments on a credit card.

However, the penalty in terms of remaining available balance is larger for credit card delinquencies. The unutilized cash equivalent balance penalty is $26 \%$ less for mortgage delinquents than for revolving credit delinquents.

\section{VI.9 Specification Choice}

As a robustness check, we evaluate the use of a probit in evaluating our problem. In Table X, we begin by adding county-level fixed effects to absorb any unobserved heterogeneity across counties in income, habits, etc. We again report the marginal effect at the average as above. Our results are consistent with those above. Because a probit imposes a functional form on the error distribution, we repeat our specification with ordinary least squares, both with and without fixed effects. As should be apparent, there is little variation in results as we alter functional form in this fashion. The combination of these provide evidence that our results are not a product of our particular estimation choice.

\section{VI.10 Income proxies}

To capture the fact that liquidity needs differ across income levels, we modify our primary measure to capture a location specific measure of income. Our robustness check here, in Table X, columns 5 and 6, is income-adjusted cash-equivalent credit availability. We can then observe the same relationship as above: higher available credit per dollar of income leads to more credit delinquencies, even controlling for total credit lines.

\section{VI.11 Assessing the Shock}

To this point, we have worked on the assumption that a given financial shock was sufficiently large to lead to a delinquency of some type. Here we conduct two exercises. First, we evaluate the correlates of having any delinquency at all. Here we add our price and liquidity variables to the baseline correlates and assess 
the delinquency decision itself. Recall that because individuals may face an exogenous shock of some type, this equation does not allow inference on the decision to become delinquent, but rather simply its correlates.

The dependent variables in Table XI is the presence of delinquency in 2007. In the first five columns, this is any delinquency, so both a credit card and a mortgage will be coded as a (1). Our sample here is all individuals that had no delinquencies in 2006. Our specification is

$$
\operatorname{pr}\left(\text { LateANY }_{i}=1\right)=\Phi\left(\alpha+\beta_{1} Y_{j}+\beta_{2} X_{i}+\beta_{3} \text { price }_{j}+\beta_{4} \text { liquidity }_{i}+\varepsilon_{i}\right)
$$

Our second exercise here is to look at the credit card and mortgage delinquencies in isolation, using the full sample of data. Note that we have not isolated the individual decision here as we did in Table XI. Instead, here we allow the full population to serve as counterfactuals. As above, this equation is non-identified, but provides additional information on the population-level correlates of each decision. In Table XII, we look specifically at each

$$
\begin{aligned}
& \operatorname{pr}\left(\text { LateRE }_{i}=1\right)=\Phi\left(\alpha+\beta_{1} Y_{j}+\beta_{2} X_{i}+\beta_{3} \text { price }_{j}+\beta_{4} \text { liquidity }_{i}+\varepsilon_{i}\right) \\
& \operatorname{pr}\left({\text { Late } \left.M T_{i}=1\right)}=\Phi\left(\alpha+\beta_{1} Y_{j}+\beta_{2} X_{i}+\beta_{3} \text { price }_{j}+\beta_{4} \text { liquidity }_{i}+\varepsilon_{i}\right)\right.
\end{aligned}
$$

As would be expected, in the aggregate, additional available credit leads to decreased delinquencies. That is, the result in the section above that lower cash-equivalent credit leads to the decision to default on a mortgage is a relative one. In absolute terms, lower liquidity leads to more defaults on both types of credit. This result highlights the importance of our identification

\section{Economic Spillovers}

This section addresses economic spillovers. Our broad finding is that the individual decision to choose to protect consumer credit instead of housing has a negative externality. In particular, it leads directly to higher foreclosures from those individuals. It also leads, indirectly, to increased local delinquencies. We attribute the latter effect to the spillover of foreclosure onto local housing prices. We illustrate this link by showing that falling housing prices are correlated with increased mortgage delinquency in Table XIII. As highlighted above, in establishing this link, it calls attention to regulatory changes, such as the CARD act, that may impact access to credit.

This section will show two phenomena. The first is a simple correlation between liquidity constraints and local delinquency rates. This is supportive of the spillover concept. The second is a relationship between 
individual level choices for a particular form of credit and local delinquency rates. To deal with potential endogeneity concerns, we will instrument delinquency choice with appropriate variables, which we discuss below.

\section{Liquidity Constraints $\Rightarrow$ Local Delinquency}

We illustrate the spillovers empirically in two stages. We begin with a simple OLS specification:

$$
\Delta \text { localDelinquency }_{j}=\alpha+\beta_{1} Y_{j}+\beta_{2} X_{i}+\beta_{3} \text { price }_{j}+\beta_{4} \text { liquidity }_{i}+\varepsilon_{i}
$$

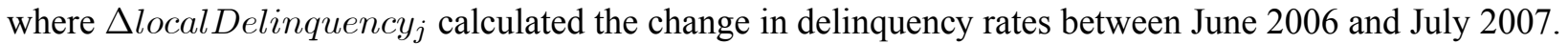
The remaining variables are the same as specified above in equation 1 . We highlight the results of this regression in Table IX. After controlling for local demographic and economic shocks as well as individual level credit characteristics, we find a strong significant relationship between housing price declines and increases in delinquency (the negative coefficient on Short Term Housing Price Change). A one standard deviation decrease in short-run housing price changes is associated with an increased revolving delinquency rate of $43 \%$ and mortgage delinquency of $42 \%$.

\section{Liquidity Constraints $\Rightarrow$ Preference for Consumer Credit $\Rightarrow$ Local Delinquency}

In this section, we extend the results from Table III, in which we showed a link from liquidity constraints to the preference for consumer credit. We show that this choice for consumer credit leads to local spillovers in the form of increased delinquency. We use two variants of a similar model, designed to capture slightly different effects. In each we use a measure designed to capture the choice to protect a particular form of credit.

The first version specifies the model:

$$
\begin{aligned}
\text { DlocalDelinquency } & =\alpha+\beta_{1} Y_{j}+\beta_{3} \text { price }_{j}+\beta_{4}(C C \prec M T)_{i}+\varepsilon_{i} \\
\operatorname{pr}(C C \prec M T)_{i} & =\Phi\left(\alpha+\beta_{1} Y_{j}+\beta_{2} X_{i}+\beta_{3} \text { price }_{j}+\beta_{4} \text { liquidity }_{i}+\varepsilon_{i}\right)
\end{aligned}
$$

where the first stage is identical to equation 1, above. Results from this specification are available in Table IX, Columns 5 and 6 . The latter of these two columns shows the impact on local mortgage delinquency rates. The negative coefficient shows that more individual choosing to protect credit cards leads to higher mortgage delinquency rates in the community. Recall that the $C C \prec M T$ that is the dependent variable in the first stage is equal to 1 if individuals choose to stop paying on their credit cards, but not their mortgages. Thus lower predicted values (negative coefficient) indicate delinquencies on mortgages. This increases local mortgage delinquency rates. 
The opposite is true for local credit card delinquency rates. More protection of credit cards leads to decreases in local revolving delinquency.

As should be apparent from equation 5 above, we instrument $C C \prec M T$ with the set of individual level credit characteristics, including the availability of credit. Our exclusion is thus that spillovers must take place through the price mechanism of foreclosures.

Because this first version limits our sample to the group of individuals studied in Table III, we expand the sample by relaxing the assumption that we need to focus on individuals that had no delinquencies in 2006 and a single type in 2007. We now use two first stage regressions, one each for mortgage and revolving delinquency:

$$
\begin{aligned}
& \Delta \text { localDelinquency }_{j}=\alpha+\beta_{1} Y_{j}+\beta_{3} \text { price }_{j}+\beta_{4}{\text { late } R E_{i}+\beta_{4} \text { late } T_{i}+\varepsilon_{i}} \\
& \operatorname{pr}\left(\text { LateRE }_{i}=1\right)=\Phi\left(\alpha+\beta_{1} Y_{j}+\beta_{2} X_{i}+\beta_{3} \text { price }_{j}+\beta_{4} \text { liquidity }_{i}+\varepsilon_{i}\right) \\
& \operatorname{pr}\left({\text { Late } \left.M T_{i}=1\right)}_{1}=\Phi\left(\alpha+\beta_{1} Y_{j}+\beta_{2} X_{i}+\beta_{3} \text { price }_{j}+\beta_{4} \text { liquidity }_{i}+\varepsilon_{i}\right)\right.
\end{aligned}
$$

The two late variables are indicator variables for each of the 60 day delinquency measures. We now include the full spectrum of individuals that became late on each form of credit. The advantage is the vastly increased sample size. The disadvantage is that we no longer can isolate the precise choice of an individual between revolving credit and mortgages; instead, we have a disaggregation of the factor influencing each choice in the absence of the other form of credit. We see in Columns 3 and 4 of Table IX that the results from this exercise are inconclusive. Increases in delinquencies on mortgages are positively associated with increases in local delinquency rates for mortgages, but no relationship shows for credit cards. For revolving debt, we observe that an increase in the individual decisions leads to an aggregate increase in revolving delinquencies as expected, but also a decline in mortgage delinquencies!

Notice the distinction in results between this specification and the first structural form. The responsiveness of revolving debt delinquency at the community level appears to have the opposite sign as a function of individual credit card delinquencies. We interpret this as being driven by the large number of individuals that have both mortgage and revolving delinquency. Our first structural model included only individuals that chose a particular type of delinquency. Regardless, the impact on mortgage delinquencies is robust to specification. 


\section{Conclusion}

This paper has found evidence on the drivers of individual delinquency decisions. In particular, our study extends existing literature by focusing on the decisions of individuals who, under moderate financial stress, consider the tradeoff between delinquency in their mortgage and their revolving credit accounts. In this regard our study contributes to the field in two important ways; first we identify a subset of the population

- those who face moderate financial shocks - that to our knowledge has not been the focus of existing studies. This subset of the population comprises of a larger percentage of individuals than does the subset that we identify as severe stress individuals (delinquency in two, as opposed to one, accounts). Second, our examination of the delinquency decision finds strong evidence that individual liquidity considerations and local housing prices are significant and robust predictors of the delinquency decision for individuals under moderate stress. Our results, that individuals may choose to preserve liquidity by stopping payments on their mortgages, counters the conventional wisdom that individuals protect their homes at all costs. Indeed, as we showed above, the results are stronger in states that had not yet experienced price declines by end of 2007.

Our analysis then examines this effect in the broader context of regional variations in delinquency rates. This extension is important, not only from a political economy perspective but also as an important qualification of the emerging literature which documents individuals decisions to become delinquent on their mortgages as a function of their debt to equity ratio on their homes. Our evidence confirms that housing prices play an important role in determining mortgage delinquencies; indeed it is one of two factors that we determine to be of particular relevance. Future research will include an analysis of supplemental data on individual mortgage balances and local housing price information to address this question explicitly.

This presence of a strong liquidity demand for credit cards has important current policy implications. Along with the financial crisis has come a large regulatory change in the credit card industry and a range of foreclosure reduction programs too numerous to describe here. For credit cards, the notable change occurred on May 22 of 2009 when the Credit Card Accountability, Responsibility, and Disclosure (CARD) Act of 2009 became law. This law limited the ability of issuers to charge a range of fees, prevented increased interest rates under many circumstances, and mandated plain language disclosures. Our results suggest that while the CARD act provided a range of regulations that are beneficial vis-a-vis assisting consumers in understanding often complex credit contracts, the direct consequence of the act will likely be to limit issuer fee income from low quality borrowers and thus may decrease access to credit for these same borrowers. We will show that reductions in limits of these borrowers in particular leads to increased mortgage delinquencies, 
counteracting some of the benefits of the foreclosure programs and potentially exacerbating a component of the crisis. On balance the CARD act is likely a positive reform; however, its unintended consequences are helpful in understanding the relatively poor performance of mortgage modification programs. As we have shown, when access to credit cards is diminished, borrowers become increasingly likely to default on their mortgages. We suspect that issuer reductions in credit lines that have occurred contemporaneously to mortgage modifications may be an important factor in understanding the fast pace of re-default in modification programs.

\section{References}

[1] Agarwal, S., P. Skiba, and J. Tobacman, 2009, Payday Loans and Credit Cards: New Liquidity and Credit Scoring Puzzles?, American Economic Review, 99(2): 412-17.

[2] Athreya, K., 2004, Shame As It Ever Was: Stigma and Personal Bankruptcy, Federal Reserve Bank of Richmond, Economic Quarterly, 90(2): 1-19.

[3] Barron, J., Elliehausen, M., Staten, M., 2000. Monitoring the Household Sector with Aggregate Credit Bureau Data. Business Economics, January.

[4] Boot, A., A. Thakor, G. Udell, 1987, Competition, Risk Neutrality, and Loan Commitments, Journal of Banking and Finance 11:449-71.

[5] Berkovitch, E. and S. Greenbaum, 1991, The Loan Commitment as an Optimal Financing Contract, Journal of Financial and Quantitative Analysis 26: 83-95

[6] Center for Responsible Lending, 2008, CRL Issue Paper: Subprime Spillover.

[7] Campello, M., Giambona, E., Graham, J. and Harvey, C., 2009, Liquidity Management and Corporate Investment During a Financial Crisis. University of Illinois, Mimeo.

[8] Carroll, S. and W. Li, 2009, The Homeownership Experience of Households in Bankruptcy, Federal Reserve Bank of Philadelphia, Working Paper 08-14.

[9] Cohen-Cole, E., 2009, The Option Value of Consumer Bankruptcy, Federal Reserve Bank of Boston, QAU Working Paper 09-01. 
[10] Cohen-Cole, E., B. Duygan-Bump, and J. Montoriol-Garriga, 2009, Forgive and Forget; Who Gets Access to Credit After Bankruptcy and Why?, Federal Reserve Bank of Boston, QAU Working Paper 09-02.

[11] Cohen-Cole, E., B. Duygan-Bump, 2010, Social influence and bankruptcy: Why do so many leave so much on the table?, University of Maryland, Mimeo.

[12] Cole, S., J. Thompson, and P. Tufano, 2008, Where Does it Go? Spending by the Financially Constrained, Harvard Business School, working paper 08-083.

[13] Dey, S., 2009, Lines of Credit and Consumption Smoothing, Bank of Canada, Working Paper 2005-18.

[14] Dick, A. and A. Lehnert, 2009, Personal Bankruptcy and Credit Market Competition, Journal of Finance, forthcoming.

[15] Fay, S., E. Hurst, and M. White, 2002, The Household Bankruptcy Decision, American Economic Review, 92(3): 706-18.

[16] Foote, C., K. Gerardi, and P. Willen, 2008, Negative equity and foreclosure: Theory and evidence, Journal of Urban Economics 6 (2), 234-245.

[17] Gross, D. and N. Souleles, 2002, An Empirical Analysis of Personal Bankruptcy and Delinquency, The Review of Financial Studies, 15(1):319-47.

[18] Guizo, L., P. Sapienza, and L. Zingales, 2009, Moral and Social Constraints to Strategic Default on Mortgages, NBER, Working Paper 15145.

[19] Holmstrom, B. and J. Tirole, 1998, Private and Public Supply of Liquidity, Journal of Political Economy 106: 1-40.

[20] Huang, R. 2009, How Committed Are Bank Lines of Credit? Evidence from the Subprime Mortgage Crisis. Federal Reserve Bank of Philadelphia, working paper.

[21] Lee, K., 2008, Foreclosure's Price-Depressing Spillover Effects on Local Properties: A Literature Review, Federal Reserve Bank of Boston, Community Affairs discussion papers 2008-01.

[22] Ludvigson, S., 1999, Consumption and Credit: A Model of Time-Varying Liquidity Constraints, The Review of Economics and Statistics, 81(3): 434-447. 
[23] Lusardi, A. and P. Tufano, 2009, Debt Literacy, Financial Experiences and Over Indebtedness, NBER working paper 14808 .

[24] Skiba, P. and J. Tobacman, 2008, Payday Loans, Consumption Shocks, and Discounting, working paper.

[25] Skiba, P. and J. Tobacman, 2008, Do Payday Loans Cause Bankruptcy?, working paper.

[26] Sullivan, T. A., E. Warren, and J. L. Westbrook, 2000, The Fragile Middle Class, Yale University Press, New Haven and London.

[27] Sullivan, T. A., E. Warren, and J. L. Westbrook, 2006, Less Stigma or More Financial Distress: An Empirical Analysis of the Extraordinary Increase in Bankruptcy Filings, Stanford Law Review 59(2): 213-256.

[28] Telyukova, I., 2009, Household Need for Liquidity and the Credit Card Debt Puzzle, working paper.

[29] Thakor, A., 2005, Do Loan Commitments Cause Overlending? Journal of Money, Credit, and Banking, 37:1067-1099

[30] Tufano, P. 2009, Consumer Finance, in A. Lo and R. Merton, Annual Review of Financial Economics

[31] White, M., 2007, Bankruptcy Reform and Credit Cards, Journal of Economic Perspectives, 21(4): 175-199.

[32] Warren, E. and A. Warren Tyagi, 2003, The Two Income Trap: Why Middle-Class Mothers \& Fathers Are Going Broke (With Surprising Solutions That Will Change Our Children's Futures), Basic Books, New York. 
TABLE I: DELINQUENCY CHOICE

Panel A:

\begin{tabular}{lll}
\hline & \multicolumn{1}{c}{$\begin{array}{c}\text { Revolving Credit } \\
\text { Delinquency }\end{array}$} & $\begin{array}{c}\text { Mortgage } \\
\text { Delinquency }\end{array}$ \\
\hline Count & 9,290 & 8,339 \\
No Delinquency of Other Type & 7,138 & 6,187 \\
$\quad$ Change & $(77 \%)$ & $(74 \%)$ \\
June 2006 - December 2007 & $18 \%$ & $127 \%$ \\
\hline
\end{tabular}

Panel B:

\begin{tabular}{ccc}
\hline & $\begin{array}{c}\text { Revolving Credit } \\
\text { Delinquency }\end{array}$ & $\begin{array}{c}\text { Mortgage } \\
\text { Delinquency }\end{array}$ \\
\hline $\begin{array}{c}\text { Change } \\
\text { June 2006 - December 2007 } \\
\text { (Nevada, California, Florida) } \\
\text { Change }\end{array}$ & $60 \%$ & $331 \%$ \\
$\begin{array}{c}\text { June 2006 - December 2007 } \\
\text { (All Other States) }\end{array}$ & $12 \%$ & $97 \%$ \\
\hline
\end{tabular}

Notes: Data is drawn from credit reports for 2.2 million individuals in June 2006 and December 2007. The numbers show those individuals that have a house and a mortgage in each of the two time periods. Delinquency is defined as 60 day delinquency at the time of the credit report. The percentage increases in both panels refer to the increase in single delinquency (e.g. mortgage delinquency and no revolving delinquency or vice versa) type

between the two time periods for the sample denoted in the row header. To create the sample, we include individuals that have at least one mortgage and at least one revolving credit line in June of 2006. We do not consider other types of debt such as car loans, personal loans or payday loans. As of 2007, we include only individuals that have incurred a delinquency on one or more mortgages or one or more cards. However, we do not include individuals that have delinquencies in cards and mortgages. We include only individuals that have a minimum total limit of 1000 and we drop top and bottom $1 \%$ of sample for mortgage, revolving total limits. 
TABLE II: DELINQUENCY PENALTIES

$\begin{array}{ccc}\text { Credit Score Penalty } & \text { Cash Equivalent Credit } & \text { Un-Utilized Cash } \\ \text { Limit Penalty } & \begin{array}{c}\text { Equivalent Credit } \\ \text { Penalty }\end{array} \\ & & \end{array}$

\begin{tabular}{|c|c|c|c|}
\hline Late Mortgage & -170 & $-18,700$ & $-8,067$ \\
\hline Late Revolving & -188 & $-9,950$ & $-10,900$ \\
\hline Number of Observations & 7,975 & 7,975 & 7,975 \\
\hline
\end{tabular}

Notes: The values reported pertain to individuals who were not delinquent in 2006, but became delinquent on either their revolving credit or mortgage debt between 2006 and 2007. The first column reports the average difference between forecast credit score, as described in the text, and actual credit score in points, the second column reports this difference for the cash equivalent credit limit, and the third column reports this difference for the un-utilized cash equivalent credit balance. Each statistic is reported for the delinquency type denoted in the row heading. All averages reported in the table exclude individuals who were delinquent in both revolving and mortgage accounts. This is calculated by estimating the following model for the credit score in 2007 using observables in 2006: $\operatorname{pr}\left(C S \_2007_{i}=1\right)=\Phi\left(\beta_{1} C S \_2006_{i}+\beta_{2} X_{\_} 2006_{i}+u_{i}\right)$ where $i$ is defined for all individuals and where $X \_2006=$ age $_{i}$, income ${ }_{i}$, race ${ }_{i}$, etc.\}, and CS_2007 and CS_2006 are the credit scores in 2007 and 2006 respectively. Then, we predict 2007 credit score for the sample of $\mathrm{i}$ individuals that have either mortgage or revolving credit delinquencies. $C S \_2007_{j}=\beta_{1} C S \_2006_{j}+\beta_{2} X \_2006_{j} T$. Finally, we estimate the credit score penalty, conditional on delinquency type, for individuals that were delinquent in 2007 by subtracting the estimated credit score in (2) from the actual observed credit score in 2007. PenaltyCC ${ }_{j}=C S \_2007_{j}$-CS_2007 $j \mid i$ was CC delinquent \& not mortgage delinquent in 2007and PenaltyMT ${ }_{j}=C S \_2007_{j}-C S \_2007_{j} \mid i$ was mortgage delinquent \& not CC delinquent in 2007. We use the same methodology for the other columns. 
TABLE IIIa: BASELINE REGRESSIONS

\begin{tabular}{|c|c|c|c|c|c|}
\hline & $\begin{array}{c}\text { Long-Term } \\
\text { Prices } \\
\end{array}$ & $\begin{array}{c}\text { Short-Term } \\
\text { Prices }\end{array}$ & Prices & Liquidity & $\begin{array}{c}\text { Prices and } \\
\text { Liquidity }\end{array}$ \\
\hline Medium Term Housing Price Change & $\begin{array}{l}-0.0810^{* * *} \\
(0.0195)\end{array}$ & & $\begin{array}{l}0.0697 * * * \\
(0.0264)\end{array}$ & & $\begin{array}{l}0.0635^{* *} \\
(0.0265)\end{array}$ \\
\hline Short Term Housing Price Change & & $\begin{array}{l}1.275^{* * *} \\
(0.141)\end{array}$ & $\begin{array}{l}1.613^{* * *} \\
(0.191)\end{array}$ & & $\begin{array}{l}1.625^{* * *} \\
(0.191)\end{array}$ \\
\hline Available Cash Equivalent Credit (thousands) & & & & $\begin{array}{l}0.00288 * * * \\
(0.000314)\end{array}$ & $\begin{array}{l}0.00295 * * * \\
(0.000316)\end{array}$ \\
\hline Divorced (\% in 1 mile radius) & $\begin{array}{l}-0.549 * * * \\
(0.195)\end{array}$ & $\begin{array}{l}-0.335^{*} \\
(0.195)\end{array}$ & $\begin{array}{l}-0.221 \\
(0.200)\end{array}$ & $\begin{array}{l}-0.326^{*} \\
(0.195)\end{array}$ & $\begin{array}{l}-0.0980 \\
(0.201)\end{array}$ \\
\hline Greater Than High School Equivalency (\% in 1 mile radius) & $\begin{array}{l}-0.210^{* *} \\
(0.0861)\end{array}$ & $\begin{array}{l}-0.122 \\
(0.0870)\end{array}$ & $\begin{array}{l}-0.119 \\
(0.0870)\end{array}$ & $\begin{array}{l}-0.270^{* * *} \\
(0.0859)\end{array}$ & $\begin{array}{l}-0.143 \\
(0.0873)\end{array}$ \\
\hline Credit Score & $\begin{array}{l}0.000506 * * * \\
(4.63 e-05)\end{array}$ & $\begin{array}{l}0.000549 * * * \\
(4.68 \mathrm{e}-05)\end{array}$ & $\begin{array}{l}0.000551^{* * *} \\
(4.68 \mathrm{e}-05)\end{array}$ & $\begin{array}{l}0.000282 * * * \\
(5.12 \mathrm{e}-05)\end{array}$ & $\begin{array}{l}0.000341^{* * *} \\
(5.18 \mathrm{e}-05)\end{array}$ \\
\hline Income Growth & $\begin{array}{l}0.000389 \\
(0.00211)\end{array}$ & $\begin{array}{l}-0.00119 \\
(0.00211)\end{array}$ & $\begin{array}{l}-0.00217 \\
(0.00214)\end{array}$ & $\begin{array}{l}-0.000104 \\
(0.00211)\end{array}$ & $\begin{array}{l}-0.00167 \\
(0.00215)\end{array}$ \\
\hline Median Household Income & $\begin{array}{l}-6.46 e-07 \\
(8.87 e-07)\end{array}$ & $\begin{array}{l}-2.15 \mathrm{e}-07 \\
(8.90 \mathrm{e}-07)\end{array}$ & $\begin{array}{l}-2.83 \mathrm{e}-07 \\
(8.91 \mathrm{e}-07)\end{array}$ & $\begin{array}{l}-1.19 \mathrm{e}-06 \\
(8.87 \mathrm{e}-07)\end{array}$ & $\begin{array}{l}-5.01 \mathrm{e}-07 \\
(8.94 \mathrm{e}-07)\end{array}$ \\
\hline No Earnings (\% in 1 mile radius) & $\begin{array}{l}0.0222 \\
(0.0818)\end{array}$ & $\begin{array}{l}0.0413 \\
(0.0808)\end{array}$ & $\begin{array}{l}0.00273 \\
(0.0821)\end{array}$ & $\begin{array}{l}-0.0610 \\
(0.0802)\end{array}$ & $\begin{array}{l}-0.00300 \\
(0.0825)\end{array}$ \\
\hline Black (\% in 1 mile radius) & $\begin{array}{l}-0.0990^{* * *} \\
(0.0343)\end{array}$ & $\begin{array}{l}-0.118^{* * *} \\
(0.0344)\end{array}$ & $\begin{array}{l}-0.119 * * * \\
(0.0345)\end{array}$ & $\begin{array}{l}-0.0831^{* *} \\
(0.0343)\end{array}$ & $\begin{array}{l}-0.111^{* * *} \\
(0.0346)\end{array}$ \\
\hline Hispanic (\% in 1 mile radius) & $\begin{array}{l}-0.204 * * * \\
(0.0569)\end{array}$ & $\begin{array}{l}-0.136^{* *} \\
(0.0576)\end{array}$ & $\begin{array}{l}-0.138 * * \\
(0.0576)\end{array}$ & $\begin{array}{l}-0.251^{* * *} \\
(0.0564)\end{array}$ & $\begin{array}{l}-0.148^{* *} \\
(0.0577)\end{array}$ \\
\hline Population Density & $\begin{array}{l}7.28 \mathrm{e}-08 \\
(1.44 \mathrm{e}-06)\end{array}$ & $\begin{array}{l}-4.77 e-07 \\
(1.43 e-06)\end{array}$ & $\begin{array}{l}-9.78 \mathrm{e}-07 \\
(1.44 \mathrm{e}-06)\end{array}$ & $\begin{array}{l}-1.23 \mathrm{e}-06 \\
(1.44 \mathrm{e}-06)\end{array}$ & $\begin{array}{l}-1.64 \mathrm{e}-06 \\
(1.45 \mathrm{e}-06)\end{array}$ \\
\hline Poverty Rate & $\begin{array}{l}0.00649 * * * \\
(0.00230)\end{array}$ & $\begin{array}{l}0.00478^{* *} \\
(0.00232)\end{array}$ & $\begin{array}{l}0.00482^{* *} \\
(0.00232)\end{array}$ & $\begin{array}{l}0.00741^{* * *} \\
(0.00229)\end{array}$ & $\begin{array}{l}0.00481^{* *} \\
(0.00232)\end{array}$ \\
\hline Public Assistance (\% in 1 mile radius) & $\begin{array}{l}-0.442^{*} \\
(0.257)\end{array}$ & $\begin{array}{l}-0.168 \\
(0.258)\end{array}$ & $\begin{array}{l}-0.213 \\
(0.259)\end{array}$ & $\begin{array}{l}-0.634 * * \\
(0.252)\end{array}$ & $\begin{array}{l}-0.189 \\
(0.259)\end{array}$ \\
\hline Unemployment Rate & $\begin{array}{l}-0.0137 * * \\
(0.00552)\end{array}$ & $\begin{array}{l}-0.00258 \\
(0.00540)\end{array}$ & $\begin{array}{l}0.00360 \\
(0.00588)\end{array}$ & $\begin{array}{l}-0.00766 \\
(0.00537)\end{array}$ & $\begin{array}{l}0.00381 \\
(0.00590)\end{array}$ \\
\hline Uninsured (health) & $\begin{array}{l}0.00208 \\
(0.00176)\end{array}$ & $\begin{array}{l}0.00107 \\
(0.00169)\end{array}$ & $\begin{array}{l}-0.000490 \\
(0.00179)\end{array}$ & $\begin{array}{l}-0.000490 \\
(0.00168)\end{array}$ & $\begin{array}{l}-0.000733 \\
(0.00179)\end{array}$ \\
\hline Age-squared & $\begin{array}{l}-0.000462^{* * *} \\
(5.58 \mathrm{e}-05)\end{array}$ & $\begin{array}{l}-0.000459 * * * \\
(5.59 \mathrm{e}-05)\end{array}$ & $\begin{array}{l}-0.000458^{* * *} \\
(5.59 \mathrm{e}-05)\end{array}$ & $\begin{array}{l}-0.000439 * * * \\
(5.63 \mathrm{e}-05)\end{array}$ & $\begin{array}{l}-0.000434^{* * * *} \\
(5.65 \mathrm{e}-05)\end{array}$ \\
\hline Age & $\begin{array}{l}0.0438^{* * *} \\
(0.00432)\end{array}$ & $\begin{array}{l}0.0436 * * * \\
(0.00433)\end{array}$ & $\begin{array}{l}0.0435 * * * \\
(0.00433)\end{array}$ & $\begin{array}{l}0.0406^{* * *} \\
(0.00436)\end{array}$ & $\begin{array}{l}0.0403 * * * \\
(0.00438)\end{array}$ \\
\hline Observations & 7975 & 7975 & 7975 & 7975 & 7975 \\
\hline
\end{tabular}

Notes: The dependent variable in each column is an indicator variable representing individuals decision to go delinquent with revolving credit (1) or with mortgage credit (0) -

individuals who went delinquent in neither and in both categories are omitted from the sample (see Table I Notes for detailed information on sample construction). We estimate the following probit model. $\operatorname{pr}(C C<M T)_{i}=\Phi\left(\alpha+\beta_{1} Y_{j}+\beta_{2} X_{i}+\beta_{3}\right.$ price $_{j}+\beta_{4}$ liquidity $\left._{i}+\varepsilon_{i}\right)$. Column 1 reports the marginal effect medium term housing price chagnes on the delinquency decision. Column 2 shows short term pricing changes. Column 3 reports both pricing changes. Column 4 and 5 inclue our liquidity measure, available revolving credit, along with the pricing changes, respectively. See Appendix T1 for a detailed description and summary statistics of each of the variables. Standard errors are reported in parentheses, and we adopt the usual convention: $* * * \mathrm{p}<0.01,{ }^{* *} \mathrm{p}<0.05, * \mathrm{p}<0.1$. 


\section{TABLE IIIb: BASELINE REGRESSIONS}

\begin{tabular}{|c|c|c|c|c|}
\hline & Liquidity-squared & $\begin{array}{l}\text { Housing Prices- } \\
\text { squared }\end{array}$ & $\begin{array}{c}\text { Liquidity and } \\
\text { Housing Prices- } \\
\text { squared } \\
\end{array}$ & Interaction Term \\
\hline $\begin{array}{l}\text { Medium Term Housing Price Change } \\
\end{array}$ & $\begin{array}{l}0.0617^{* *} \\
(0.0266)\end{array}$ & $\begin{array}{l}0.146 \\
(0.139)\end{array}$ & $\begin{array}{l}0.153 \\
(0.140)\end{array}$ & $\begin{array}{l}0.0758^{* * *} \\
(0.0294)\end{array}$ \\
\hline Short Term Housing Price Change & $\begin{array}{l}1.623 * * * \\
(0.192)\end{array}$ & $\begin{array}{l}1.468 * * * \\
(0.323)\end{array}$ & $\begin{array}{l}1.453 * * * \\
(0.323)\end{array}$ & $\begin{array}{l}1.586^{* * * *} \\
(0.218)\end{array}$ \\
\hline Available Cash Equivalent Credit (thousands) & $\begin{array}{l}0.00595 * * * \\
(0.000593)\end{array}$ & $\begin{array}{l}0.00295 * * * \\
(0.000316)\end{array}$ & $\begin{array}{l}0.00595^{* * *} \\
(0.000593)\end{array}$ & $\begin{array}{l}0.00389^{* * *} \\
(0.000824)\end{array}$ \\
\hline Available Cash Equivalent Credit (thousands)-squared & $\begin{array}{l}-2.71 \mathrm{e}-05^{* * *} \\
(4.39 \mathrm{e}-06)\end{array}$ & & $\begin{array}{l}-2.72 \mathrm{e}-05^{* * *} \\
(4.40 \mathrm{e}-06)\end{array}$ & \\
\hline Short Term Housing Price Change-squared & & $\begin{array}{l}-0.499 \\
(4.280)\end{array}$ & $\begin{array}{l}-0.393 \\
(4.285)\end{array}$ & \\
\hline Medium Term Housing Price Change-squared & & $\begin{array}{l}-0.0616 \\
(0.103)\end{array}$ & $\begin{array}{l}-0.0685 \\
(0.103)\end{array}$ & \\
\hline Available Cash Equivalent Credit (thousands) X Short Term Housing Price & & & & $\begin{array}{l}0.00263 \\
(0.00815)\end{array}$ \\
\hline Available Cash Equivalent Credit (thousands) X MediumTerm Housing Price & & & & $\begin{array}{l}-0.00103 \\
(0.000999)\end{array}$ \\
\hline Divorced (\% in 1 mile radius) & $\begin{array}{l}-0.0916 \\
(0.201)\end{array}$ & $\begin{array}{l}-0.0979 \\
(0.201)\end{array}$ & $\begin{array}{l}-0.0911 \\
(0.201)\end{array}$ & $\begin{array}{l}-0.0925 \\
(0.201)\end{array}$ \\
\hline Greater Than High School Equivalency (\% in 1 mile radius) & $\begin{array}{l}-0.148^{*} \\
(0.0875)\end{array}$ & $\begin{array}{l}-0.146^{*} \\
(0.0876)\end{array}$ & $\begin{array}{l}-0.152^{*} \\
(0.0878)\end{array}$ & $\begin{array}{l}-0.144^{*} \\
(0.0873)\end{array}$ \\
\hline Credit Score & $\begin{array}{l}0.000259 * * * \\
(5.36 \mathrm{e}-05)\end{array}$ & $\begin{array}{l}0.000341^{* * *} \\
(5.18 \mathrm{e}-05)\end{array}$ & $\begin{array}{l}0.000259 * * * \\
(5.36 \mathrm{e}-05)\end{array}$ & $\begin{array}{l}0.000332 * * * \\
(5.21 \mathrm{e}-05)\end{array}$ \\
\hline Income Growth & $\begin{array}{l}-0.00167 \\
(0.00216)\end{array}$ & $\begin{array}{l}-0.00182 \\
(0.00217)\end{array}$ & $\begin{array}{l}-0.00185 \\
(0.00218)\end{array}$ & $\begin{array}{l}-0.00160 \\
(0.00215)\end{array}$ \\
\hline Median Household Income & $\begin{array}{l}-5.24 \mathrm{e}-07 \\
(8.96 \mathrm{e}-07)\end{array}$ & $\begin{array}{l}-5.62 \mathrm{e}-07 \\
(9.00 \mathrm{e}-07)\end{array}$ & $\begin{array}{l}-5.92 \mathrm{e}-07 \\
(9.01 \mathrm{e}-07)\end{array}$ & $\begin{array}{l}-5.02 \mathrm{e}-07 \\
(8.94 \mathrm{e}-07)\end{array}$ \\
\hline No Earnings (\% in 1 mile radius) & $\begin{array}{l}-1.39 \mathrm{e}-05 \\
(0.0827)\end{array}$ & $\begin{array}{l}-0.00413 \\
(0.0830)\end{array}$ & $\begin{array}{l}-0.000958 \\
(0.0831)\end{array}$ & $\begin{array}{l}-0.000786 \\
(0.0825)\end{array}$ \\
\hline Black (\% in 1 mile radius) & $\begin{array}{l}-0.110 * * * \\
(0.0346)\end{array}$ & $\begin{array}{l}-0.111^{* * *} \\
(0.0349)\end{array}$ & $\begin{array}{l}-0.109 * * * \\
(0.0349)\end{array}$ & $\begin{array}{l}-0.110 * * * \\
(0.0346)\end{array}$ \\
\hline Hispanic (\% in 1 mile radius) & $\begin{array}{l}-0.153^{* * * *} \\
(0.0578)\end{array}$ & $\begin{array}{l}-0.152 * * * \\
(0.0581)\end{array}$ & $\begin{array}{l}-0.157 * * * \\
(0.0581)\end{array}$ & $\begin{array}{l}-0.149 * * * \\
(0.0577)\end{array}$ \\
\hline Population Density & $\begin{array}{l}-1.93 \mathrm{e}-06 \\
(1.45 \mathrm{e}-06)\end{array}$ & $\begin{array}{l}-1.64 \mathrm{e}-06 \\
(1.47 \mathrm{e}-06)\end{array}$ & $\begin{array}{l}-1.92 \mathrm{e}-06 \\
(1.47 \mathrm{e}-06)\end{array}$ & $\begin{array}{l}-1.67 \mathrm{e}-06 \\
(1.45 \mathrm{e}-06)\end{array}$ \\
\hline Poverty Rate & $\begin{array}{l}0.00493 * * \\
(0.00232)\end{array}$ & $\begin{array}{l}0.00473^{* *} \\
(0.00233)\end{array}$ & $\begin{array}{l}0.00483 * * \\
(0.00233)\end{array}$ & $\begin{array}{l}0.00487 * * \\
(0.00232)\end{array}$ \\
\hline Public Assistance (\% in 1 mile radius) & $\begin{array}{l}-0.154 \\
(0.259)\end{array}$ & $\begin{array}{l}-0.190 \\
(0.264)\end{array}$ & $\begin{array}{l}-0.156 \\
(0.264)\end{array}$ & $\begin{array}{l}-0.193 \\
(0.259)\end{array}$ \\
\hline Unemployment Rate & $\begin{array}{l}0.00341 \\
(0.00591)\end{array}$ & $\begin{array}{l}0.00369 \\
(0.00596)\end{array}$ & $\begin{array}{l}0.00324 \\
(0.00597)\end{array}$ & $\begin{array}{l}0.00372 \\
(0.00590)\end{array}$ \\
\hline Uninsured (health) & $\begin{array}{l}-0.000753 \\
(0.00179)\end{array}$ & $\begin{array}{l}1.32 \mathrm{e}-05 \\
(0.00233)\end{array}$ & $\begin{array}{l}3.64 \mathrm{e}-05 \\
(0.00234)\end{array}$ & $\begin{array}{l}-0.000626 \\
(0.00180)\end{array}$ \\
\hline Age-squared & $\begin{array}{l}-0.000425^{* * *} \\
(5.64 \mathrm{e}-05)\end{array}$ & $\begin{array}{l}-0.000434^{* * *} \\
(5.65 \mathrm{e}-05)\end{array}$ & $\begin{array}{l}-0.000425^{* * *} \\
(5.65 \mathrm{e}-05)\end{array}$ & $\begin{array}{l}-0.000438^{* * *} \\
(5.66 \mathrm{e}-05)\end{array}$ \\
\hline Age & $\begin{array}{l}0.0392 * * * \\
(0.00438)\end{array}$ & $\begin{array}{l}0.0404 * * * \\
(0.00438)\end{array}$ & $\begin{array}{l}0.0392^{* * *} \\
(0.00438)\end{array}$ & $\begin{array}{l}0.0405^{* * *} \\
(0.00438)\end{array}$ \\
\hline Observations & 7975 & 7975 & 7975 & 7975 \\
\hline
\end{tabular}




\section{TABLE IVa: ALTERNATE SOURCES OF LIQUIDITY}

\begin{tabular}{|c|c|c|c|c|}
\hline \multirow{2}{*}{\multicolumn{5}{|c|}{ Other Types of Credit }} \\
\hline & & & & \\
\hline \multirow[t]{2}{*}{ Medium Term Housing Price Change } & $0.0624 * *$ & $0.0700^{* * *}$ & $0.0643^{* *}$ & $0.0737 * * *$ \\
\hline & $(0.0266)$ & $(0.0265)$ & $(0.0265)$ & $(0.0265)$ \\
\hline \multirow[t]{2}{*}{ Short Term Housing Price Change } & $1.585^{* * *}$ & $1.629 * * *$ & $1.618^{* * *}$ & $1.623 * * *$ \\
\hline & $(0.192)$ & $(0.191)$ & $(0.191)$ & $(0.191)$ \\
\hline \multirow[t]{2}{*}{ Available Cash Equivalent Credit (2006) } & $0.00279 * * *$ & & & \\
\hline & $(0.000319)$ & & & \\
\hline \multirow[t]{2}{*}{ Available Home Equity Line of Credit (2006) } & $2.07 \mathrm{e}-06^{* * *}$ & & & \\
\hline & $(5.01 \mathrm{e}-07)$ & & & \\
\hline \multirow[t]{2}{*}{ Available Credit (thousands) - Retail Cards (2006) } & & $0.0225^{* * *}$ & & \\
\hline & & $(0.00252)$ & & \\
\hline \multirow[t]{2}{*}{ Available Credit (thousands) - Revolving Bank (2006) } & & & $0.00263 * * *$ & \\
\hline & & & $(0.000343)$ & \\
\hline \multirow[t]{2}{*}{ Available Credit (thousands) - Other (2006) } & & & & $0.00232 * * *$ \\
\hline & & & & $(0.000719)$ \\
\hline individual controls & $\mathrm{X}$ & $\mathrm{X}$ & $\mathrm{X}$ & $\mathrm{X}$ \\
\hline local demographic variables & $\mathrm{X}$ & $\mathrm{X}$ & $\mathrm{X}$ & $\mathrm{X}$ \\
\hline local financial variables & $\mathrm{X}$ & $\mathrm{X}$ & $\mathrm{X}$ & $\mathrm{X}$ \\
\hline Observations & 7,975 & 7,975 & 7,975 & 7,975 \\
\hline
\end{tabular}

Notes: The numbers reported are the marginal effects based on coefficients estimated using a probit model. The dependent variable is an indicator representing individuals decision to go delinquent with revolving credit (1) or with mortgage credit (0) - individuals who went delinquent in neither and in both categories are omitted from the sample (see Table I Notes for detailed information on sample construction). These regressions are estimated as

$\operatorname{pr}(C C<M T)_{i}=\Phi\left(\alpha+\beta_{1} Y_{j}+\beta_{2} X_{i}+\beta_{3}\right.$ price $_{j}+\beta_{4}$ liquidity $_{i}+\beta_{5}$ price $_{j}{ }^{2}+\beta_{6}$ liquidity $_{i}{ }^{2}+\beta_{7}$ price $_{j} *$ liquidity $\left.+\varepsilon_{i}\right)$. The first column adds to the baseline specification (Column 5 of Table IIIa) a measure of available home-equity credit. Columns 2,3 , and 4 include alternative measures of available liquidity. Unreported included controls include the divorce rate in area, high school education rate in area, credit score for the individual, income growth in the area, median income in area, \% individuals with no earnings in area, \%Black in area, \%Hispanic in area, population density in area, povery rate in area, public assistance rate in area, unemployment rate in area, medically uninsured rate in area, age of individual, age-squared of individual. Available credit - retail cards is the difference between limit and balance on retail store and department store lines of credit. Available credit - bank cards is the difference between limit and balance on lines of credit issues by banks, including cards branded along with Visa, Mastercard, Discover, and American Express. Available credit - other is the difference between limit and balance on all types of revolving credit other than bank cards, retail cards and HELOCs. Standard errors are reported in parentheses, and we adopt the usual convention: ${ }^{* * *} \mathrm{p}<0.01,{ }^{* *} \mathrm{p}<0.05, * \mathrm{p}<0.1$. See Table I notes for information on sample construction. 
TABLE IVb: ALTERNATE SOURCES OF LIQUIDITY

\begin{tabular}{|c|c|c|c|}
\hline Dependent Variable & $<100$ Lenders & 100-550 Lenders & >550 Lenders \\
\hline \multirow[t]{2}{*}{ Medium Term Housing Price Change } & -0.00188 & -0.120 & $0.0972 * *$ \\
\hline & $(0.0714)$ & $(0.100)$ & $(0.0388)$ \\
\hline \multirow[t]{2}{*}{ Short Term Housing Price Change } & -0.494 & $1.206^{*}$ & $1.753^{* * *}$ \\
\hline & $(1.051)$ & $(0.694)$ & $(0.295)$ \\
\hline \multirow[t]{2}{*}{ Available Cash Equivalent Credit (2006) } & $0.00328 * * *$ & $0.00400^{* * *}$ & $0.00267 * * *$ \\
\hline & $(0.000652)$ & $(0.000966)$ & $(0.000394)$ \\
\hline \multirow[t]{2}{*}{ Average Payday Loan (dollars) } & -0.000442 & -0.000338 & 0.000245 \\
\hline & $(0.000329)$ & $(0.000791)$ & $(0.000201)$ \\
\hline \multirow[t]{2}{*}{ Average Payday Loan (APR) } & 0.000133 & 0.000258 & $0.000376^{* *}$ \\
\hline & $(0.000318)$ & $(0.000296)$ & $(0.000166)$ \\
\hline individual controls & $\mathrm{X}$ & $\mathrm{X}$ & $\mathrm{X}$ \\
\hline local demographic variables & $\mathrm{X}$ & $\mathrm{X}$ & $\mathrm{X}$ \\
\hline local financial variables & $\mathrm{X}$ & $\mathrm{X}$ & $\mathrm{X}$ \\
\hline Observations & 1,735 & 1,274 & 4,966 \\
\hline
\end{tabular}
Notes: The numbers reported are the marginal effects based on coefficients estimated using a probit model. The dependent variable is an indicator representing
individuals decision to go delinquent with revolving credit (1) or with mortgage credit (0) - individuals who went delinquent in neither and in both categories are omitted from the sample (see Table I Notes for detailed information on sample construction). These regressions are estimated as

$\operatorname{pr}(C C<M T)_{i}=\Phi\left(\alpha+\beta_{1} Y_{j}+\beta_{2} X_{i}+\beta_{3}\right.$ price $_{j}+\beta_{4}$ liquidity $_{i}+\beta_{5}$ averageloan $\left._{j}+\beta_{6} A P R_{i}+\varepsilon i\right)$. The first column includes individuals who live in a state no payday lenders, as well as the controls from the baseline regression, the first column pertains to states with fewer than 100 payday lenders, the second column pertains to states with between 100 and 550 payday lenders, and the last column pertains to states with more than 550 payday lenders. Payday lending information is courtesy of Professor Steven Graves. Unreported included controls include the divorce rate in area, high school education rate in area, credit score for the individual, income growth in the area, median income in area, \% individuals with no earnings in area, \%Black in area, \%Hispanic in area, population density in area, povery rate in area, public assistance rate in area, unemployment rate in area, medically uninsured rate in area, age of individual, age-squared of individual. Payday_avgloan indicatese the average loan size in the state. Payday_apr is the maximum permitted annual percentage rate on payday loans in the state. Standard errors are reported in parentheses, and we adopt the usual convention: *** $\mathrm{p}<0.01, * * \mathrm{p}<0.05$, * $\mathrm{p}<0.1$. See Table I notes for information on sample construction. 
TABLE Va: DELINQUENCY REGRESSION RESULTS

\begin{tabular}{|c|c|c|c|c|c|}
\hline Dependent Variable & $\begin{array}{c}\text { Delinquent (any } \\
\text { account) } \\
(2007) \\
\end{array}$ & $\begin{array}{c}\text { Delinquent (any } \\
\text { account) } \\
(2007) \\
\end{array}$ & $\begin{array}{c}\text { Delinquent (any } \\
\text { account) } \\
(2007) \\
\end{array}$ & $\begin{array}{c}\text { Delinquent (any } \\
\text { account) } \\
(2007) \\
\end{array}$ & $\begin{array}{c}\text { Delinquent (any } \\
\text { account) } \\
(2007) \\
\end{array}$ \\
\hline Medium Term Housing Price Change & $\begin{array}{l}0.00519 * * * \\
(0.000538)\end{array}$ & & & $\begin{array}{l}-0.00208^{* * *} \\
(0.000663)\end{array}$ & $\begin{array}{l}-0.00206^{* * *} \\
(0.000672)\end{array}$ \\
\hline Short Term Housing Price Change & & $\begin{array}{l}-0.0702 * * * \\
(0.00379)\end{array}$ & & $\begin{array}{l}-0.0787 * * * \\
(0.00477)\end{array}$ & $\begin{array}{l}-0.0795 * * * \\
(0.00483)\end{array}$ \\
\hline Available Cash Equivalent Credit (2006) & & & $\begin{array}{l}-0.000142^{* * *} \\
(6.40 \mathrm{e}-06)\end{array}$ & $\begin{array}{l}-0.000142^{* * *} \\
(6.25 \mathrm{e}-06)\end{array}$ & $\begin{array}{l}-0.000245^{* * *} \\
(1.25 \mathrm{e}-05)\end{array}$ \\
\hline Available Cash Equivalent Credit -squared & & & & & $\begin{array}{l}8.35 \mathrm{e}-07 * * * \\
(8.25 \mathrm{e}-08)\end{array}$ \\
\hline individual controls & $\mathrm{X}$ & $\mathrm{X}$ & $\mathrm{X}$ & $\mathrm{X}$ & $\boldsymbol{X}$ \\
\hline local demographic variables & $\mathrm{X}$ & $\mathrm{X}$ & $\mathrm{X}$ & $\mathrm{X}$ & $\boldsymbol{X}$ \\
\hline local financial variables & $\mathrm{X}$ & $\mathrm{X}$ & $\mathrm{X}$ & $\mathrm{X}$ & $\boldsymbol{X}$ \\
\hline Observations & 351,366 & 351,366 & 351,366 & 351,366 & 351,366 \\
\hline
\end{tabular}

Notes: The numbers reported are the marginal effects at the mean based on coefficients estimated using a probit model. See Appendix T1 for a detailed description of each of the variables. These regressions are estimated using the full sample of individuals who had no deliquencies in June of 2006. We estimated using

$\operatorname{pr}\left(\right.$ LateANY $\left._{i}=1\right)=\Phi\left(\alpha+\beta_{1} Y_{j}+\beta_{2} X_{i}+\beta_{3}\right.$ price $_{j}+\beta_{4}$ liquidity $\left._{i}+\varepsilon_{i}\right)$. The dependent variable is an indicator variable which takes the value of 1 when an individual has a delinquency in either their mortgage or their revolving credit accounts. Unreported included controls include the divorce rate in area, high school education rate in area, credit score for the individual, income growth in the area, median income in area, \% individuals with no earnings in area, \%Black in area, \%Hispanic in area, population density in area, povery rate in area, public assistance rate in area, unemployment rate in area, medically uninsured rate in area, age of individual, agesquared of individual. The sample in all columns is limited to individuals who have only one delinquency or no delinquencies in 2007 and no delinquencies in 2006. Standard errors are reported in parentheses, and we adopt the usual convention: *** $\mathrm{p}<0.01,{ }^{* *} \mathrm{p}<0.05,{ }^{*} \mathrm{p}<0.1$. 
TABLE Vb: DELINQUENCY REGRESSION RESULTS

\begin{tabular}{|c|c|c|c|c|}
\hline Dependent Variable & $\begin{array}{c}\text { Delinquent Mortgage } \\
\text { Account } \\
(2007) \\
\end{array}$ & $\begin{array}{c}\text { Delinquent Mortgage } \\
\text { Account } \\
(2007) \\
\end{array}$ & $\begin{array}{c}\text { Delinquent Revolving } \\
\text { Account } \\
(2007)\end{array}$ & $\begin{array}{c}\text { Delinquent Revolving } \\
\text { Account } \\
\text { (2007) }\end{array}$ \\
\hline \multirow[t]{2}{*}{ Medium Term Housing Price Change } & $-0.00129^{* * *}$ & $-0.00133^{* * *}$ & -0.000382 & -0.000371 \\
\hline & $(0.000375)$ & $(0.000391)$ & $(0.000555)$ & $(0.000558)$ \\
\hline \multirow[t]{2}{*}{ Short Term Housing Price Change } & $-0.0495 * * *$ & $-0.0517 * * *$ & $-0.0314 * * *$ & $-0.0315^{* * *}$ \\
\hline & $(0.00283)$ & $(0.00291)$ & $(0.00399)$ & $(0.00400)$ \\
\hline \multirow[t]{2}{*}{ Available Cash Equivalent Credit (2006) } & $-9.84 \mathrm{e}-05^{* * *}$ & $-0.000163^{* * *}$ & $-6.49 \mathrm{e}-05^{* * *}$ & $-9.38 \mathrm{e}-05^{* * *}$ \\
\hline & $(4.01 \mathrm{e}-06)$ & $(7.86 e-06)$ & $(4.91 \mathrm{e}-06)$ & $(1.06 \mathrm{e}-05)$ \\
\hline \multirow[t]{2}{*}{ Available Cash Equivalent Credit -squared } & & $5.75 \mathrm{e}-07 * * *$ & & $2.29 \mathrm{e}-07 * * *$ \\
\hline & & $(5.29 \mathrm{e}-08)$ & & $(7.21 \mathrm{e}-08)$ \\
\hline individual controls & $\mathrm{X}$ & $\mathrm{X}$ & $\mathrm{X}$ & $\mathrm{X}$ \\
\hline local demographic variables & $\mathrm{X}$ & $\mathrm{X}$ & $\mathrm{X}$ & $\mathrm{X}$ \\
\hline local financial variables & $\mathrm{X}$ & $\mathrm{X}$ & $\mathrm{X}$ & $\mathrm{X}$ \\
\hline Observations & 351,366 & 351,366 & 351,366 & 351,366 \\
\hline
\end{tabular}

Notes: The numbers reported are the marginal effects at the mean based on coefficients estimated using a probit model. See Appendix T1 for a detailed description of each of the variables. These regressions are estimated using the full sample of individuals who had no deliquencies in June of 2006 . We estimate the first two columns using $\operatorname{pr}\left(\right.$ LateRE $\left._{i}=1\right)=\Phi\left(\alpha+\beta_{1} Y_{j}+\beta_{2} X_{i}+\beta_{3}\right.$ price $_{j}+\beta_{4}$ liquidity $\left._{i}+\varepsilon_{i}\right)$ and in the last two columns we estimate

$\operatorname{pr}\left(\right.$ LateRE $\left._{i}=1\right)=\Phi\left(\alpha+\beta_{1} Y_{j}+\beta_{2} X_{i}+\beta_{3}\right.$ price $_{j}+\beta_{4}$ liquidity $\left._{i}+\varepsilon_{i}\right)$. The dependent variable in the first and second columns is an indicator variable which takes the value of 1 when an individual is mortgage delinquent. The dependent variable in the final two columns is an indicator variable which takes the value of 1 when an individual is revolving credit delinquent. Unreported included controls include the divorce rate in area, high school education rate in area, credit score for the individual, income growth in the area, median income in area, \% individuals with no earnings in area, \%Black in area, \%Hispanic in area, population density in area, povery rate in area, public assistance rate in area, unemployment rate in area, medically uninsured rate in area, age of individual, age-squared of individual. The sample in all columns is limited to individuals who have only one delinquency or no delinquencies in 2007 and no delinquencies in 2006 . Standard errors are reported in parentheses, and we adopt the usual convention: $* * * \mathrm{p}<0.01, * * \mathrm{p}<0.05, * \mathrm{p}<0.1$. 


\section{TABLE VI: AGE AND CREDIT SCORES}

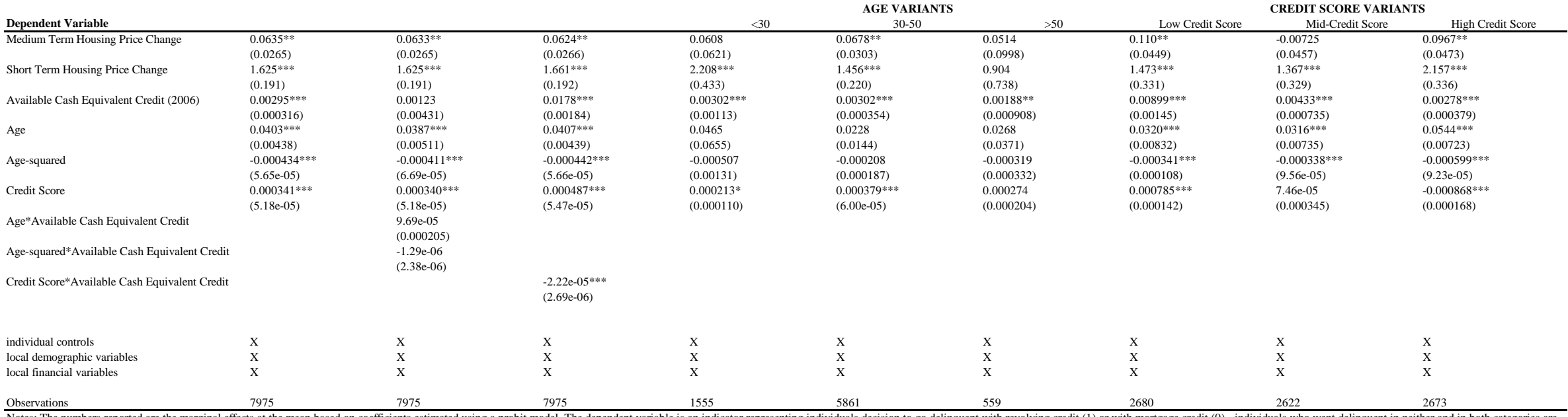

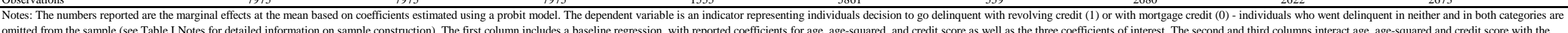
omitted from the sample (see Table I Notes for detailed information on sample construction). The first column includes a baseline regression, with reported coefficients for age, age-squared, and credit score as well as the three coefficients of interest. The second and third columns interact age, age-squared and credit score with the

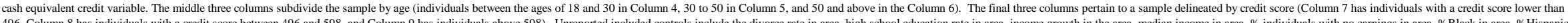

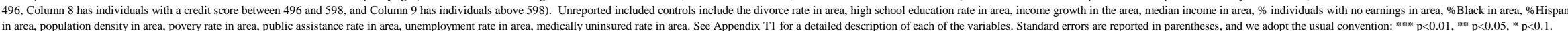




\section{TABLE VII: SPECIFICATION CHOICE}

\begin{tabular}{|c|c|c|c|c|c|c|}
\hline Dependent Variable & Delinquency Decision & Fixed-Effect Probit & OLS & $\begin{array}{c}\text { Fixed-Effect } \\
\text { OLS } \\
\end{array}$ & Alternate Definition & $\begin{array}{c}\text { Fixed-Effect } \\
\text { Alternate Definition } \\
\end{array}$ \\
\hline Medium Term Housing Price Change & $\begin{array}{l}0.0635^{* *} \\
(0.0265)\end{array}$ & $\begin{array}{l}0.0533^{*} \\
(0.0294)\end{array}$ & $\begin{array}{l}0.0611^{* *} \\
(0.0251)\end{array}$ & $\begin{array}{l}0.0547^{* *} \\
(0.0265)\end{array}$ & $\begin{array}{l}0.111^{* * *} \\
(0.0271)\end{array}$ & $\begin{array}{l}0.101^{* * *} \\
(0.0307)\end{array}$ \\
\hline Short Term Housing Price Change & $\begin{array}{l}1.625^{* * *} \\
(0.191)\end{array}$ & $\begin{array}{l}1.584^{* * *} \\
(0.218)\end{array}$ & $\begin{array}{l}1.532 * * * \\
(0.180)\end{array}$ & $\begin{array}{l}1.506 * * * \\
(0.194)\end{array}$ & $\begin{array}{l}0.968^{* * *} \\
(0.199)\end{array}$ & $\begin{array}{l}0.936 * * * \\
(0.231)\end{array}$ \\
\hline Available Cash Equivalent Credit (2006) & $\begin{array}{l}0.00295^{* * *} \\
(0.000316)\end{array}$ & $\begin{array}{l}0.00299 * * * \\
(0.000319)\end{array}$ & $\begin{array}{l}0.00258^{* * *} \\
(0.000275)\end{array}$ & $\begin{array}{l}0.00259^{* * *} \\
(0.000275)\end{array}$ & & \\
\hline Income Adjusted Available Cash Equivalent Credit (2006) & & & & & $\begin{array}{l}100.1 * * * \\
(16.06)\end{array}$ & $\begin{array}{l}101.2 * * * \\
(16.27)\end{array}$ \\
\hline Income Adjusted Mortgage Balance (2006) & & & & & $\begin{array}{l}-54.31 * * * \\
(3.155)\end{array}$ & $\begin{array}{l}-55.89^{* * *} \\
(3.233)\end{array}$ \\
\hline Income Adjusted Revolving Credit Balance (2006) & & & & & $\begin{array}{l}153.3^{* * *} \\
(13.17)\end{array}$ & $\begin{array}{l}157.4^{* * *} \\
(13.38)\end{array}$ \\
\hline individual controls & $\mathrm{x}$ & $\mathrm{x}$ & $\mathrm{X}$ & $\mathrm{X}$ & $\mathrm{x}$ & $\mathrm{x}$ \\
\hline local demographic variables & $\mathrm{x}$ & $\mathrm{X}$ & $\mathrm{X}$ & $\mathrm{X}$ & $\mathrm{X}$ & $\mathrm{x}$ \\
\hline local financial variables & $\mathrm{x}$ & $\mathrm{x}$ & $\mathrm{x}$ & $\mathrm{x}$ & $\mathrm{x}$ & $\mathrm{X}$ \\
\hline probit model & $\mathrm{x}$ & $\mathrm{x}$ & & & $\mathrm{x}$ & $\mathrm{x}$ \\
\hline OLS model & & & $\mathrm{X}$ & $\mathrm{X}$ & & \\
\hline Fixed Effects (state-county) & & $\mathrm{X}$ & & $\mathrm{X}$ & & $\mathrm{X}$ \\
\hline $\begin{array}{l}\text { Observations } \\
\text { R-squared }\end{array}$ & 7,975 & 7,975 & $\begin{array}{l}7,975 \\
0.073\end{array}$ & 7,975 & 7,963 & 7,963 \\
\hline
\end{tabular}

Notes: The dependent variable in each column is an indicator variable representing individuals decision to go delinquent with revolving credit (1) or with mortgage credit (0) - individuals who went delinquent in neither and in both

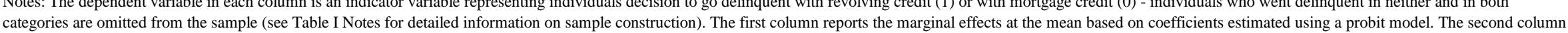
categories are omitted from the sample (see Table I Notes for detailed information on sample construction). The first column reports the marginal effects at the mean based on coefficients estimated using a probit model. The second
repeats this exercise using a fixed effects model where the panel variable is the state and county of residence. The third and fourth columns repeat the exercising using linear regression models. Columns five and six offer a different definition for available credit: available cash-equivalent credit divided by local median income, as well as two additional measures of income adjusted credit. The first is mortgage balance divided by local median income and the second

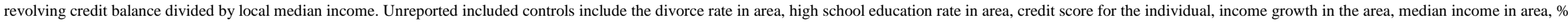
individuals with no earnings in area, \%Black in area, \%Hispanic in area, population density in area, povery rate in area, public assistance rate in area, unemployment rate in area, medically uninsured rate in area, age of individual, agesquared of individual. See Appendix T1 for a detailed description of each of the variables. Standard errors are reported in parentheses, and we adopt the usual convention: ${ }^{* * *} \mathrm{p}<0.01$, ${ }^{* *} \mathrm{p}<0.05$, ${ }^{*} \mathrm{p}<0.1$ 


\section{TABLE VIII: DISTRESSED STATES}

\begin{tabular}{|c|c|c|c|c|c|c|c|c|}
\hline Dependent Variable & & & ied States & & & & ressed States & \\
\hline Medium Term Housing Price Change & $\begin{array}{l}0.0376 \\
(0.0562)\end{array}$ & $\begin{array}{l}0.0433 \\
(0.0564)\end{array}$ & 0.217 & $\begin{array}{l}0.0398 \\
(0.0564)\end{array}$ & $\begin{array}{l}0.102^{* *} \\
(0.0399)\end{array}$ & $\begin{array}{l}0.100^{* *} \\
(0.03999\end{array}$ & 0.236 & $\begin{array}{l}0.101^{* *} \\
(0.03999\end{array}$ \\
\hline Short Term Housing Price Change & $1.586^{* * *}$ & $1.570^{* * *}$ & -0.238 & $1.422 * * *$ & 0.833 & 0.830 & 1.099 & 0.828 \\
\hline & $(0.547)$ & $(0.548)$ & $(2.236)$ & $(0.550)$ & $(0.568)$ & $(0.568)$ & $(1.537)$ & $(0.568)$ \\
\hline Available Cash Equivalent Credit (2006) & $0.00258^{* * *}$ & $0.00579 * * *$ & $0.00580 * * *$ & $-0.00223 * *$ & $0.00338 * * *$ & $0.00596 * * *$ & $0.00595^{* * *}$ & $0.00277^{* * * *}$ \\
\hline Available Cash Equivalent Credit (thousands)-squared & $(0.000421)$ & $\begin{array}{l}(0.000843) \\
-2.64 \mathrm{e}-05 * * *\end{array}$ & $\begin{array}{l}(0.000843) \\
-2.66 \mathrm{e}-05 * * *\end{array}$ & (0.00102) & & $\begin{array}{l}(0.000829) \\
-2.66 \mathrm{e}-05^{* * *}\end{array}$ & $\begin{array}{l}(0.000829) \\
-2.66 \mathrm{e}-05^{* * *}\end{array}$ & \\
\hline & & $(5.90 \mathrm{e}-06)$ & $(5.90 \mathrm{e}-06)$ & & & $(6.65 \mathrm{e}-06)$ & $(6.66 \mathrm{e}-06)$ & \\
\hline Medium Term Housing Price Change-squared & & & -0.117 & & & & -0.103 & \\
\hline & & & $(0.210)$ & & & & $(0.163)$ & \\
\hline Short Term Housing Price Change-squared & & & -17.03 & & & & -9.061 & \\
\hline Available Home Equity Line of Credit (2006) & & & (23.46) & $\begin{array}{l}0.00455 * * * \\
(0.000890)\end{array}$ & & & $(19.64)$ & $\begin{array}{l}0.000586 \\
(0.000630)\end{array}$ \\
\hline individual controls & $\mathrm{x}$ & $\mathrm{x}$ & $\mathrm{x}$ & $\mathrm{x}$ & $\mathrm{x}$ & $\mathrm{x}$ & $\mathrm{x}$ & $\mathrm{x}$ \\
\hline local demographic variables & $\mathrm{x}$ & $\mathrm{x}$ & $\mathrm{x}$ & $\mathrm{x}$ & $\mathrm{x}$ & $\mathrm{x}$ & $\mathrm{x}$ & $\mathrm{x}$ \\
\hline local financial variables & $\mathrm{x}$ & $\mathrm{x}$ & $\mathrm{x}$ & $\mathrm{x}$ & $\mathrm{x}$ & $\mathrm{x}$ & $\mathrm{x}$ & $\mathrm{x}$ \\
\hline Observations & 3,212 & 3,212 & 3,212 & 3,212 & 4,763 & 4,763 & 4,763 & 4,763 \\
\hline
\end{tabular}

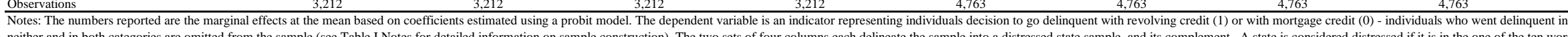
neither and in both categories are omitted from the sample (see Table I Notes for detailed information on sample construction). The two sets of four columns each delineate the sample into a distressed state sample, and its complement. A state is considered distressed if it is in the one of the ten wo

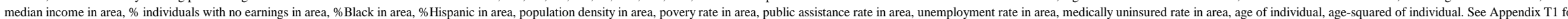
a detailed description of each of the variables. Standard errors are reported in parentheses, and we adopt the usual convention: *** $p<0.01, * * p<0.05,{ }^{*} p<0.1$ 
TABLE IX: SPILLOVERS

OLS

Change in Local

Revolving Delinquency

Dependent Variable

$0.000955^{* *}$

$0.000955^{* *}$

$(0.000469)$

$-0.0433^{* *}$
$(0.00330)$

$-9.00 \mathrm{e}-06^{* * *}$

(2.73e-06)

Available Cash Equivalent Credit (2006)

Indicator of Delinquent Revolving Credit Account (2006)

Indicator of Delinquent Mortgage Account (2006)

Delinquency Choice (1 - Revolving, 0 - Mortgage)

\section{Change in Local}

V Regression: Indicator Variables

IV Regression:

Change in

ortgage Delinquency

IV Regression: Delinquency Decision

Change in Local

Change in Local

(IVreg)

$-0.00211^{* * *}$
$(0.000451)$
$-0.0957^{* * *}$
$(0.00318)$
$-2.18 \mathrm{e}-05^{* *}$
$(2.62 \mathrm{e}-06)$

$0.00106^{* *}$

$(0.000447)$

$-0.0351^{* * *}$

(IVreg)

$-0.00137^{* * *}$

$(0.000438)$ (Ivreg_sub) $-0.0106^{*}$ (0.00586) 0.0692

(0.00334)

(0.0508)

$-0.00764$

(0.00598)

$(0.00340)$

$-0.0822 * * *$

$\begin{array}{ll}0.179^{* * *} & -0.0822 * * * \\ (0.0270) & (0.0265) \\ -0.00305 & 0.260^{* * *} \\ (0.0224) & (0.0220)\end{array}$

(0.0224)

(0.0220)

$0.141^{* * *}-0.215^{* * *}$

$(0.0134) \quad(0.0136)$

individual controls

local demographic variables

local financial variables

OLS

Instrumental Variable Regression

Observations

R-squared

$\mathrm{x} \quad \mathrm{x}$

$\begin{array}{ll}X & X \\ X & x \\ X & x\end{array}$

$\begin{array}{ll}\mathrm{X} & \mathrm{X} \\ \mathrm{X} & \mathrm{X} \\ \mathrm{X}\end{array}$

0.005

0.005

$\mathrm{X}$
$\mathrm{X}$
$\mathrm{X}$

$x$

$\mathrm{X}$
$\mathrm{X}$
$\mathrm{X}$

351,366

351,36

$x$

$x \quad x$

作

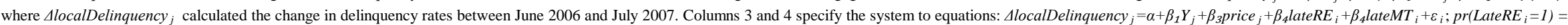
$\Phi\left(\alpha+\beta_{1} Y_{j}+\beta_{2} X_{i}+\beta_{3}\right.$ price $_{j}+\beta_{4}$ liquidity $\left._{i}+\varepsilon_{i}\right) ; \operatorname{pr}\left(\right.$ LateMT $\left._{i}=1\right)=\Phi\left(\alpha+\beta_{1} Y_{j}+\beta_{2} X_{i}+\beta_{3}\right.$ price $_{j}+\beta_{4}$ liquidity $\left._{i}+\varepsilon_{i}\right)$ and columns 5 and 6 use:

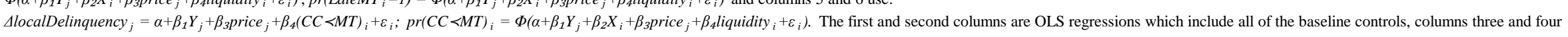
are instrumental variable regressions which include a subset of the baseline controls and have as instruments the binary choices for delinquency in credit and mortgage accounts, and columns five and six are instrumental variable regressions which include a subset of the baseline controls and have as an instrument the binary choice of delinquency in either revolving or mortgage credit (based on the sample from the baseline regression). Unreported included controls include the divorce rate in area, high school education rate in area, credit score for the individual, income growth in the area, median income in area, \% individuals with no earnings in area, \%Black in area, \%Hispanic in area, population density in area, povery rate in area, public assistance rate in area, unemployment rate in area, medically uninsured rate in area, age of individual, age-squared of individual. See Appendix T1 for a detailed description of each of the variables. Standard errors are povery rate in area, public assistance rate in area, unemployment rate in area, medically unins
reported in parentheses, and we adopt the usual convention: $* * * \mathrm{p}<0.01,{ }^{* *} \mathrm{p}<0.05, * \mathrm{p}<0.1$ 
TABLE X: SCALE OF PAYMENTS

\begin{tabular}{|c|c|c|c|c|c|c|c|}
\hline & (1) & (2) & (3) & (4) & (5) & (6) & (7) \\
\hline Medium Term Housing Price Change & $\begin{array}{l}0.0635^{* *} \\
(0.0265)\end{array}$ & $\begin{array}{l}0.0912 * * * \\
(0.0269)\end{array}$ & $\begin{array}{l}0.0894 * * * \\
(0.0269)\end{array}$ & $\begin{array}{l}0.205 \\
(0.141)\end{array}$ & $\begin{array}{l}0.0684^{* *} \\
(0.0274)\end{array}$ & $\begin{array}{l}0.0669 * * \\
(0.0274)\end{array}$ & $\begin{array}{l}0.208 \\
(0.144)\end{array}$ \\
\hline Short Term Housing Price Change & $\begin{array}{l}1.625 * * * \\
(0.191)\end{array}$ & $\begin{array}{l}1.594 * * * \\
(0.194)\end{array}$ & $\begin{array}{l}1.595 * * * \\
(0.194)\end{array}$ & $\begin{array}{l}1.379 * * * \\
(0.326)\end{array}$ & $\begin{array}{l}1.693 * * * \\
(0.198)\end{array}$ & $\begin{array}{l}1.693 * * * \\
(0.198)\end{array}$ & $1.409 * * *$ \\
\hline Available Cash Equivalent Credit (2006) & $\begin{array}{l}0.00295^{* * *} \\
(0.000316)\end{array}$ & $\begin{array}{l}0.00185 * * * \\
(0.000318)\end{array}$ & $\begin{array}{l}0.00346 * * * \\
(0.000621)\end{array}$ & $\begin{array}{l}0.00347^{* * * *} \\
(0.000621)\end{array}$ & $\begin{array}{l}0.00255^{* * *} \\
(0.000321)\end{array}$ & $\begin{array}{l}0.00503^{* * *} \\
(0.000608)\end{array}$ & $\begin{array}{l}0.00503^{* * *} \\
(0.000608)\end{array}$ \\
\hline Mortgage Payment less Revolving Credit Payment & & $\begin{array}{l}-7.75 \mathrm{e}-05 * * * \\
(4.65 \mathrm{e}-06)\end{array}$ & $\begin{array}{l}-7.51 \mathrm{e}-05^{* * *} \\
(4.71 \mathrm{e}-06)\end{array}$ & $\begin{array}{l}-7.52 \mathrm{e}-05 * * * \\
(4.71 \mathrm{e}-06)\end{array}$ & & & \\
\hline Mortgage Payment as multiple of Revolving Credit & & & & & $\begin{array}{l}-1.82 \mathrm{e}-05 \\
(1.22 \mathrm{e}-05)\end{array}$ & $\begin{array}{l}-1.72 \mathrm{e}-05 \\
(1.22 \mathrm{e}-05)\end{array}$ & $\begin{array}{l}-1.72 \mathrm{e}-05 \\
(1.22 \mathrm{e}-05)\end{array}$ \\
\hline Available Cash Equivalent Credit (thousands)-squared & & & $\begin{array}{l}-1.41 \mathrm{e}-05^{* * *} \\
(4.57 \mathrm{e}-06)\end{array}$ & $\begin{array}{l}-1.42 \mathrm{e}-05^{* * *} \\
(4.57 \mathrm{e}-06)\end{array}$ & & $\begin{array}{l}-2.22 \mathrm{e}-05^{* * * *} \\
(4.50 \mathrm{e}-06)\end{array}$ & $\begin{array}{l}-2.23 \mathrm{e}-05^{* * * *} \\
(4.50 \mathrm{e}-06)\end{array}$ \\
\hline Medium Term Housing Price Change-squared & & & & $\begin{array}{l}-0.0865 \\
(0.104)\end{array}$ & & & $\begin{array}{l}-0.105 \\
(0.106)\end{array}$ \\
\hline Short Term Housing Price Change-squared & & & & $\begin{array}{l}-0.478 \\
(4.328)\end{array}$ & & & $\begin{array}{l}-1.566 \\
(4.424)\end{array}$ \\
\hline individual controls & $\mathrm{x}$ & $\mathrm{x}$ & $\mathrm{x}$ & $\mathrm{x}$ & $\mathrm{x}$ & $\mathrm{x}$ & $\mathrm{X}$ \\
\hline local demographic variables & $\mathrm{x}$ & $\mathrm{x}$ & $\mathrm{x}$ & $\mathrm{x}$ & $\mathrm{x}$ & $\mathrm{x}$ & $\mathrm{x}$ \\
\hline local financial variables & $\mathrm{x}$ & $\mathrm{x}$ & $\mathrm{x}$ & $\mathrm{x}$ & $\mathrm{x}$ & $\mathrm{x}$ & $\mathrm{x}$ \\
\hline Observations & 7,975 & 7,975 & 7,975 & 7,975 & 7,463 & 7,463 & 7,463 \\
\hline
\end{tabular}

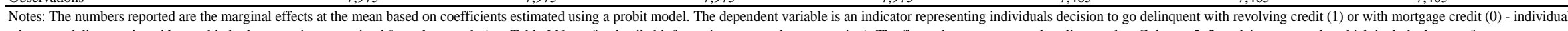
who went delinquent in neither and in both categories are omitted from the sample (see Table I Notes for detailed information on sample construction). The first column reports our baseline results. Columns 2 , 3, and 4 report results which include the net of mortgage

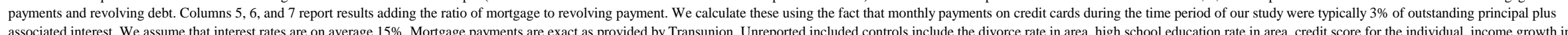
associated interest. We assume that interest rates are on average $15 \%$. Mortgage payments are exact as provided by Transunion. Unreported included controls include the divorce rate in area, high school education rate in area, credit score for the individual, income growth in
the area, median income in area, \% individuals with no earnings in area, \%Black in area, \%Hispanic in area, population density in area, povery rate in area, public assistance rate in area, unemployment rate in area, medically uninsured rate in area, age of individual, agesquared of individual. See Appendix T1 for a detailed description of each of the variables. Standard errors are reported in parentheses, and we adopt the usual convention: ${ }^{* * *} \mathrm{p}<0.01,{ }^{* *} \mathrm{p}<0.05$, ${ }^{*} \mathrm{p}<0.1$. 
APPENDIX T-I: SUMMARY STATISTICS

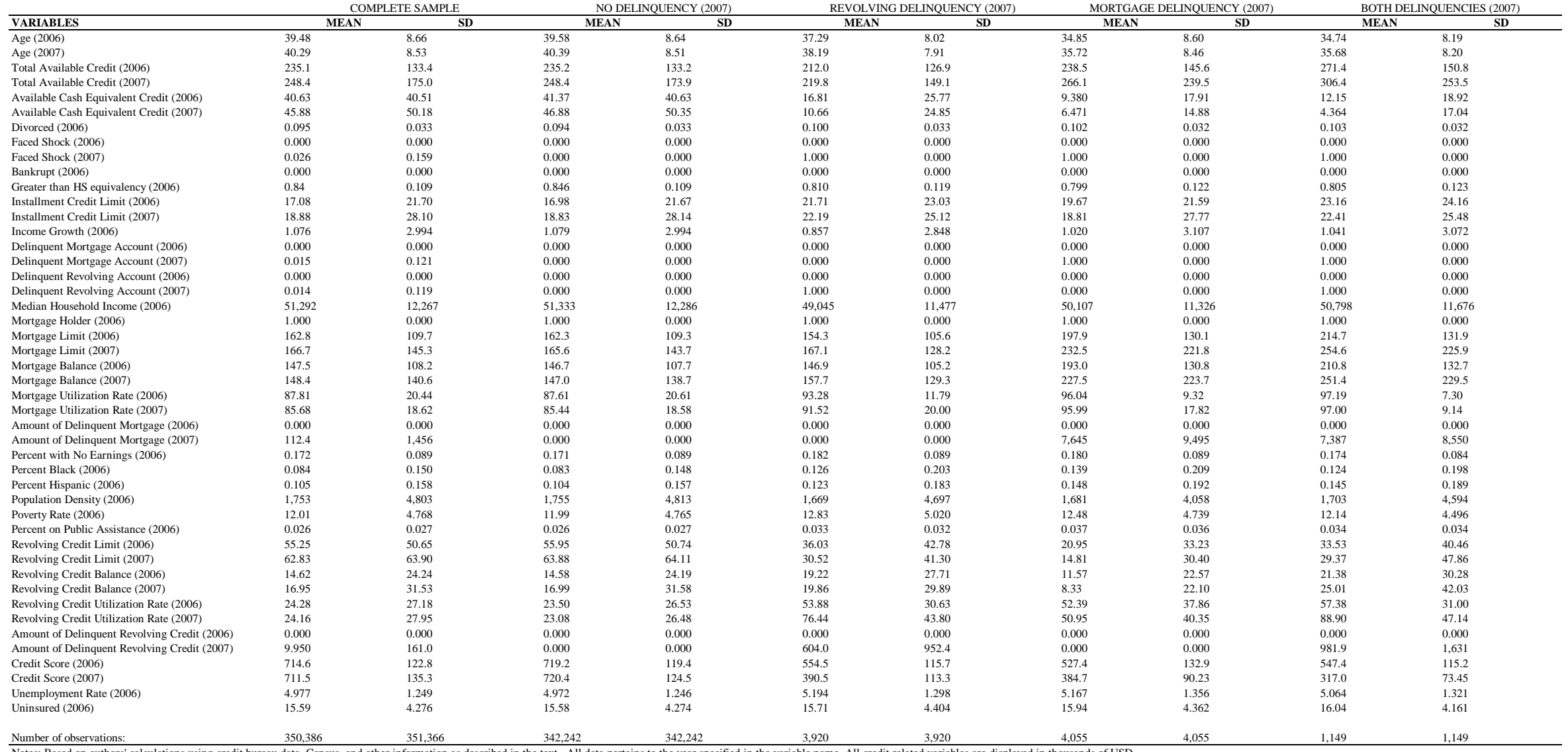

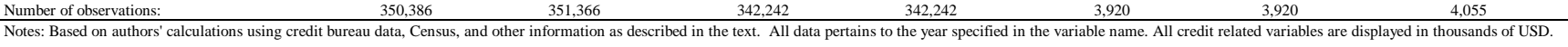

